\title{
The Intestinal Barrier-Shielding the Body from Nano- and Microparticles in Our Diet
}

\author{
Marlene Schwarzfischer and Gerhard Rogler *(D) \\ Department of Gastroenterology \& Hepatology, University Hospital Zurich, 8091 Zurich, Switzerland; \\ marlene.schwarzfischer@usz.ch \\ * Correspondence: gerhard.rogler@usz.ch; Tel.: +41-44-255-11-11
}

check for updates

Citation: Schwarzfischer, M.; Rogler, G. The Intestinal Barrier-Shielding the Body from Nano- and Microparticles in Our Diet. Metabolites 2022, 12, 223. https:// doi.org/10.3390/metabo12030223

Academic Editors: Eva Rath and Mathias Chamaillard

Received: 19 January 2022

Accepted: 28 February 2022

Published: 2 March 2022

Publisher's Note: MDPI stays neutral with regard to jurisdictional claims in published maps and institutional affiliations.

Copyright: (C) 2022 by the authors. Licensee MDPI, Basel, Switzerland. This article is an open access article distributed under the terms and conditions of the Creative Commons Attribution (CC BY) license (https:// creativecommons.org/licenses/by/ $4.0 /)$.

\begin{abstract}
Nano- and microparticles are an implicit part of the human diet. They are unknowingly ingested with our food that contains them as additives or pollutants. However, their impact on human health is not yet understood and controversially discussed. The intestinal epithelial barrier shields our body against exogenous influences, such as commensal bacteria, pathogens, and bodyforeign particles and, therefore, protects our body integrity. Breakdown of the intestinal epithelial barrier and aberrant immune responses are key events in the pathogenesis of inflammatory bowel disease (IBD). Epithelial lesions might enable systemic translocation of nano- and microparticles into the system, eventually triggering an excessive immune response. Thus, IBD patients could be particularly vulnerable to adverse health effects caused by the ingestion of synthetic particles with food. The food-additive titanium dioxide $\left(\mathrm{TiO}_{2}\right)$ serves as a coloring agent in food products and is omnipresent in the Western diet. $\mathrm{TiO}_{2}$ nanoparticles exacerbate intestinal inflammation by activation of innate and adaptive immune response. Because of serious safety concerns, the use of $\mathrm{TiO}_{2}$ as a food additive was recently banned from food production within the European Union. Due to environmental pollution, plastic has entered the human food chain, and plastic microparticles have been evidenced in the drinking water and comestible goods. The impact of plastic ingestion and its resulting consequences on human health is currently the subject of intense research. Focusing on $\mathrm{TiO}_{2}$ and plastic particles in the human diet and their impact on epithelial integrity, gut homeostasis, and intestinal inflammation, this review is addressing contemporary hot topics which are currently attracting a lot of public attention.
\end{abstract}

Keywords: epithelial cells; intestinal mucosa; nanoparticles; titanium dioxide; inflammasome; microplastic; nanoplastic

\section{Introduction}

The intestinal epithelial is critical for absorbing nutrients and shielding the body from harmful exogenous factors. It is composed of a single layer of intestinal epithelial cells (IEC) sealed by multi-protein complexes called tight junctions, which control the passage of water, ion, and solutes through the paracellular way [1-3]. IECs restrict the entrance of commensal bacteria by secretion of mucin and anti-microbial molecules while tight junctions prevent the entry of pathogens and regulate electrolyte secretion. Furthermore, they selectively allow for the access of antigens derived from food or commensal bacteria to induce oral tolerance $[4,5]$. Therefore, it is evident that disruption of the epithelial barrier may lead to mucosal inflammation [6].

Disturbances of the mucosal epithelial barrier contribute to the pathogenesis of inflammatory bowel diseases (IBD) and other systemic conditions. IBD is a term for a group of chronic disorders of the gastrointestinal tract (GIT) which are characterized by relapsing inflammation [7]. Considering the manifestation of the inflammation, IBD can be sub-divided into two primary conditions: Crohn's disease (CD) may affect any part of the digestive system from the mouth to the anus [7], whereas ulcerative colitis (UC) is restricted to the 
large bowel, with pronounced inflammation in the rectum [7]. Triggered by genetic and environmental risk factors, IBD has become a prototype for a multifactorial disease [7,8]. IBD onset is characterized by dysregulation of intestinal homeostasis, triggered by epithelial barrier defects, altered immune response, and dysbiosis of the gut microbiome [9] (Figure 1). This imbalance subsequently results in bacterial translocation across the intestinal barrier and provokes aberrant activation of inflammatory cascades [10]. A leaky intestinal barrier with increased intestinal permeability was first reported more than 20 years ago in patients with CD [11]. However, for decades, it was not clear whether it was a cause or result of the disease. A recent patient study supports the hypothesis that the breakdown of the epithelial barrier is a causative key event in CD pathogenesis and may serve as a biomarker for CD onset [12].

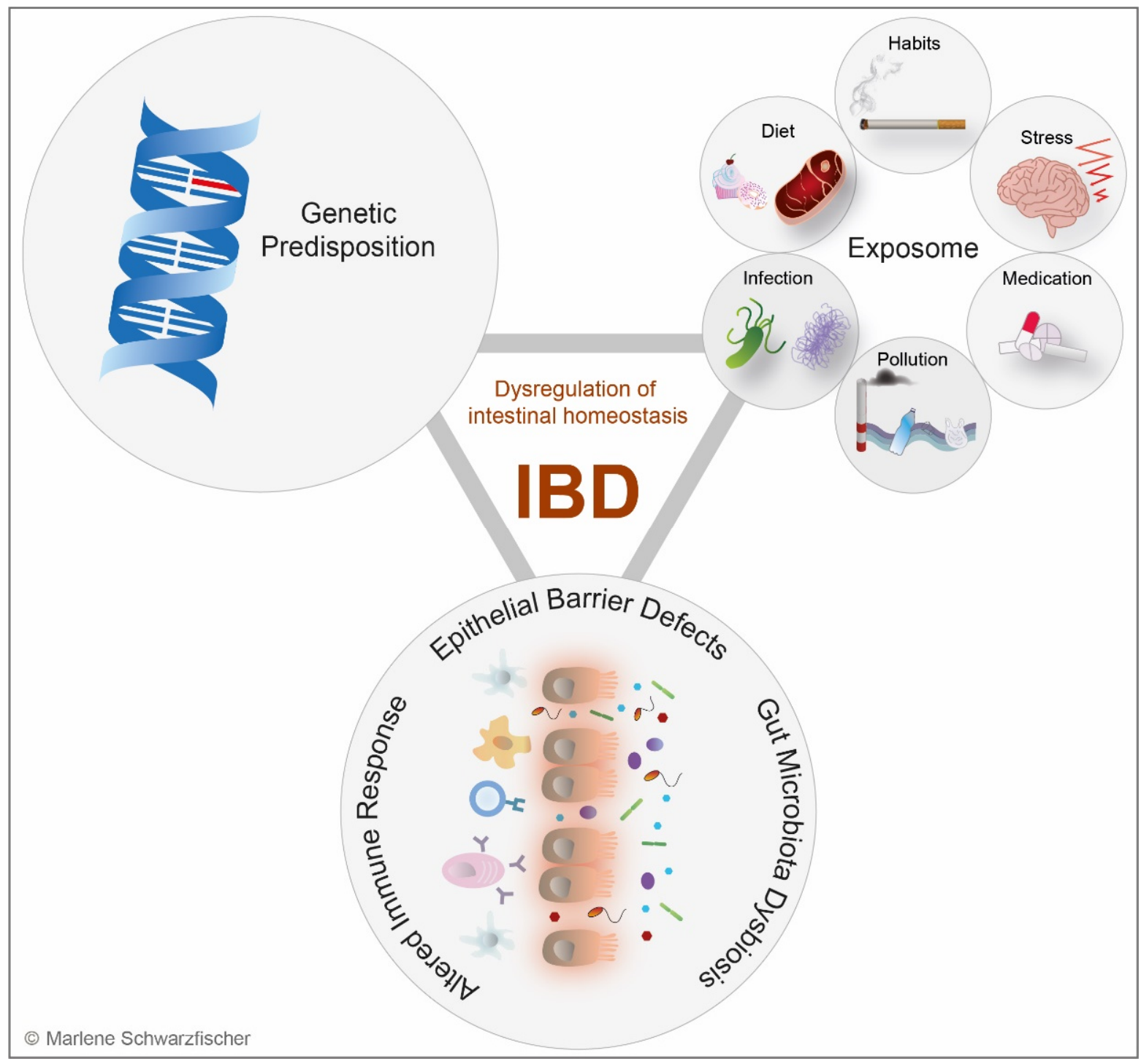

Figure 1. IBD - a multifactorial disease. IBD pathogenesis is driven by an interplay of genetic and environmental risk factors, causing epithelial barrier defects, microbial dysbiosis, and excessive upor downregulation of the immune response, which culminates in dysregulation of the intestinal homeostasis and intestinal inflammation. Environmental factors can influence the onset and course of IBD and are collectively referred to as the exposome. For example, cigarette smoking, stress, medication, air and water pollution, infections, and dietary preferences were shown to modulate IBD risk. 
There is evidence that IECs are activated and that the epithelial barrier integrity is disturbed in IBD patients even before the onset of intestinal inflammation [13-16]. In CD, increased epithelial permeability might result from a decreased expression of the tight junction proteins occludin, claudin $5 / 8$, and increased presence of the pore-forming protein claudin 2 [17]. In UC, apoptosis of IECs causes focal epithelial lesions, which are mainly responsible for the observed barrier dysfunction [17-19]. Furthermore, overexpression of pro-inflammatory cytokines, including tumor necrosis factor (TNF) and interferon (IFN) $\gamma$, modulate tight junctions, induce apoptosis in epithelial cells and, therefore, impair barrier integrity in IBD patients [20-23]. Increased permeability subsequently allows highpenetration of antigens and loss of essential ions and water, resulting in diarrhea $[19,20]$. Genetic variants in genes belonging to the Janus kinases (JAKs) and signal transducers and activators of transcription (STATs) have been associated with epithelial barrier defects and increased IBD risk. Barrier integrity is regulated by the JAK-STAT signaling pathway, controlling paracellular permeability and epithelial cell death. Suppression of these signaling cascades was proven to have a substantial therapeutic potential for IBD treatment [23]. Assessment of intestinal barrier integrity is tricky, as demonstrated recently by Power et al. refuting several studies that proclaimed barrier-associated molecules zonula occludens 1 (ZO-1) and intestinal fatty acid-binding proteins (I-FABP) to be sufficient serological markers for quantification of epithelial damage. Based on these findings, the authors raise the question of whether physiologic measurement of intestinal permeability necessarily correlates with changes in tight junction structures [24]. In turn, increased anti-microbial antibody responses have been associated with an elevated CD risk and may serve as an early pre-disease marker for CD onset [25].

\section{Environmental Factors Contribute to Epithelial Activation and Barrier Defects}

Environmental risk factors for IBD are numerous and almost inevitably present in our daily life, and their impact on IBD risk, onset, and the disease course can hardly be captured. Disease-relevant external factors are collectively referred to as the exposome. This index allows assessment of the total environmental (non-genetic) exposure individuals face during their lifetime and estimation of the resulting impact on their health [26]. In terms of IBD, the most relevant environmental factors associated with the disease are personal habits, psychological stress, medication, environmental pollution, infection, and diet [8,27] (Figure 1).

Progressing with industrialization, environmental pollution is increasing around the globe. Global plastic contamination is one of the biggest challenges of our times. The increasing abundance of NP and MP particles in the human diet raises concerns about their safety and potential impacts on gastrointestinal health. Previous studies reported that plastic ingestion might affect barrier integrity and induce histological changes, alterations of gut physiology, and gut microbiota dysbiosis [28-32]. Rising exposure to air pollutants such as sulfur dioxide $\left(\mathrm{SiO}_{2}\right)$, nitric oxide $(\mathrm{NO})$, and particulate matter was suspected to increase the risk of IBD onset [27,33-35]. In addition, air pollutants were hypothesized to alter the microbiome composition and therefore modify IBD risk. However, associations are complex and require further studies [36,37]. The impact of water pollutants on IBD risk is of great interest as antagonists of steroid receptors, endocrine-disrupting chemicals, phthalic acid, and nonylphenols, evidenced in bottled water, might interfere with therapy targeting the steroid hormone metabolism [8,27,38-41].

Our diet is an important exogenous factor that plays an undisputed role in IBD onset and progression $[8,27,42,43]$. Our dietary habits might impact IBD risk and disease outcome in several ways, directly modulating the gut microbiome, influencing the intestinal barrier's integrity and permeability, and affecting the immune system [42]. Strikingly, dietary changes can alter the intestinal microbiome within $24 \mathrm{~h}$ [43]. Specific diets have been associated with a reduced or increased IBD risk [44].

Dietary management, aiming for a balanced diet, was said to impact the disease course positively and, therefore, improve the well-being of IBD patients [45-48]. For 
example, high dietary fiber intake was shown to modify the gut microbiome composition beneficially and to reduce intestinal inflammation [49]. Furthermore, a high fiber diet has been associated with a decreased CD risk [50]. In addition, flavonoids were found to possess anti-inflammatory capacities and suppress intestinal inflammation via modulation of the enteroendocrine system [51].

In contrast, food antigens might be an important trigger of intestinal inflammation as most IBD patients report intolerance to certain dietary constituents [52]. Western diet, rich in sugar, animal proteins, and polyunsaturated fatty acids (PUFAs), might predispose to IBD [53-56]. Several studies have shown that the Western diet promotes intestinal inflammation via modulation of barrier integrity and the gut microbiome, resulting in altered gut homeostasis [53,57-63]. A high-sugar diet affected the intestinal epithelial integrity in mice, increased their susceptibility to dextran sodium sulfate (DSS)-induced colitis, and altered their gut microbiome [64]. Similar findings were made when mice were fed a diet rich in animal protein, which resulted in pro-inflammatory macrophages' response and exacerbation of DSS-induced colitis [55]. A high-fat diet was shown to induce oxidative stress in the murine mucosa, triggering mucosal inflammation and increasing barrier permeability [65]. Western diet is characterized by an imbalance of n-3 and n-6 PFUAs in favor of n-6 PFUAs $[66,67]$. Although epidemiologic studies identified n-3 PFUAs to have anti-inflammatory properties and prevent UC, high n-6 PFUAs consumption was found to significantly increase the risk for UC onset and other inflammatory diseases [66]. Considering the rising prevalence and incidence of IBD in westernized countries around Asia, North America, and the Middle East, diet westernization seems likely to be the significant driver of IBD around the globe [27,59,68-70].

Food products from the Western world are often processed and preserved using food additives to optimize flavor, color, and texture artificially. A recent review by Raoul et al. nicely describes the associations of food additives and IBD concerning alterations in the gut microbiome and impacts on gastrointestinal homeostasis [71]. Food-processing often involves the usage of nano-additives [72], including silver (Ag) (E174), iron oxide (FeO) $(\mathrm{E} 172)$, silicon dioxide $\left(\mathrm{SiO}_{2}\right)(\mathrm{E} 551)$, and titanium dioxide $\left(\mathrm{TiO}_{2}\right)(\mathrm{E} 171)$ nanoparticles, which are nowadays an implicit part of the human diet. Ghebretatios et al. recently assessed the use of nanoparticles in the food industry and the impact of nanoparticleinduced microbiota changes in the pathogenesis of intestinal diseases [72]. Penetration of the intestinal epithelium by body-foreign particles is determined by their diameter $[73,74]$. It is assumed that, due to their smaller size, nanoparticles possess higher bioavailability which allows for increased translocation into the system. Body-foreign particles below $150 \mu \mathrm{m}$ in diameter penetrate the intestinal epithelium, while micro- and nano-sized particles below $2.5 \mu \mathrm{m}$ in diameter are absorbed by microfold cells (M-cells) in Payer's patches [73]. Therefore, it needs to be investigated more closely whether the ingestion of nano- and microparticles with our diet may adversely affect human health, especially gastrointestinal homeostasis.

\section{3. $\mathrm{TiO}_{2}$ in the Human Diet-A Constant Companion}

Dietary preferences are tightly linked to the unintentional consumption of food additives, such as stabilizers, antioxidants, flavor enhancers, or food coloring agents. Due to its shiny, white, and bright appearance, $\mathrm{TiO}_{2}$ is a popular food-coloring agent and is highly abundant in the Western diet $[75,76] . \mathrm{TiO}_{2}$ nanoparticles find use in comestible goods, medicine, and personal care products to optimize their appearance and to meet customers preferences [76,77].

Following the Codex Alimentarius, published by a committee of experts delegated from the Food and Agriculture Organization (FAO) and the World Health Organization (WHO), forming the Joint FAO/WHO Expert Committee on Food Additives (JECFA), the use of food-grade $\mathrm{TiO}_{2}$ was approved by the United States Food and Drug Administration (USFDA) in 1966 as first [78,79] and three years later by the European Food Safety Authority (EFSA) [79,80]. EFSA permitted the use of $\mathrm{TiO}_{2}$ for milk and dairy products, 
cheese products, preparation of fruits and vegetables, chewing gums, confectionery, edible ices, decorations, coatings and fillings of pastry and fine bakery ware, breakfast cereals, processed nuts, noodles, batters, the casing of meat products, processing of fish and fishery products, sauces, salad toppings, soups and broths, protein and dietary foods, flavored drinks, alcoholic drinks, and other foodstuffs [80]. Popular non-food sources of oral $\mathrm{TiO}_{2}$ intake are toothpaste and pills [81]. By 2016, the global volume consumption of $\mathrm{TiO}_{2}$ nanoparticles exceeded 6 million metric tons, and consumption is projected to increase further [82], pushing the market to USD 14.12 billion by 2021 [83]. $\mathrm{TiO}_{2}$ mainly occurs in three structures: brookite, rutile, and anatase, whereby only rutile and anatase particles may be used in food [84]. The size of the particles found in food products varies between 10-350 nm, with a relevant fraction of particles below $100 \mathrm{~nm}$ [75,85-88]. According to a regulation from the European Commission in 2011, the use of $\mathrm{TiO}_{2}$ in food must be indicated in the list of ingredients, and the application of $\mathrm{TiO}_{2}$ nanoparticles must be explicitly labeled [89]. Following the permission by the USFDA, food products from the US may contain up to $1 \%$ of $\mathrm{TiO}_{2}$ nanoparticles [78], while previously, the European Union (EU) allowed the use of $\mathrm{TiO}_{2}$ at quantum satis [90]. By October 2021, the EU Commission-based on a new evaluation of risks of $\mathrm{TiO}_{2}$ by the EFSA—banned $\mathrm{TiO}_{2}$ from being used as a food additive from 2022.

Dietary $\mathrm{TiO}_{2}$ intake seems to be culturally different, and consumption ranges from micrograms to milligrams per kilogram body weight $\left(\mathrm{kg}_{\mathrm{BW}}\right)$, depending on nutritional and personal habits $[75,76,81,91]$. Germany's mean dietary $\mathrm{TiO}_{2}$ intake ranges between 0.5 and $1 \mathrm{mg} \mathrm{TiO} 2 / \mathrm{kg}_{\mathrm{BW}}$ for adults and $2 \mathrm{mg} \mathrm{TiO} / 2 / \mathrm{kg}_{\mathrm{BW}}$ for children [91]. For the US population, the daily $\mathrm{TiO}_{2}$ exposure is believed to range between 1 and $2 \mathrm{mg} \mathrm{TiO} / 2 / \mathrm{kg}_{\mathrm{BW}}$ for children and 0.2 and $0.7 \mathrm{mg} \mathrm{TiO} / 2 / \mathrm{kg}_{\mathrm{BW}}$ for adults [92]. With children consuming $2-3 \mathrm{mg} \mathrm{TiO} / 2 / \mathrm{kg}_{\mathrm{BW}} /$ day and adults ingesting $1 \mathrm{mg} \mathrm{TiO}{ }_{2} / \mathrm{kg}_{\mathrm{BW}} /$ day, $\mathrm{TiO}_{2}$ consumption is even higher in the United Kingdom [92]. High $\mathrm{TiO}_{2}$ contents were evidenced in chewing gums, candy, and fine bakery wares [75], reaching up to $2.5 \mathrm{mg} \mathrm{TiO}_{2}$ per gram of food [75,91]. Due to their preference for sweets, children and teenagers are highly exposed. Their estimated maximum consumption is up to $32.4 \mathrm{mg} \mathrm{TiO} 2 / \mathrm{kg}_{\mathrm{BW}} /$ day $[75,76]$. Chewing one single bubblegum might result in an intake of $5 \mathrm{mg} \mathrm{TiO}$, while powdered donuts can contain up to $100 \mathrm{mg} \mathrm{TiO}_{2}$ per serving [92].

A risk assessment conducted by the FDA in 1969 classified $\mathrm{TiO}_{2}$ to be safe in use, and the definition of an acceptable daily intake was considered unnecessary [93]. However, this decision was based on only five publications, reporting low solubility of the compound and absence of significant effects in animal experiments, suggesting low bioactivity, absorption rates, and minor accumulation in the body [77]. Re-evaluations by the Scientific Committee on Food (SCF) in 1975 and 1977 did not entail any regulatory limits for the use of $\mathrm{TiO}_{2}$ [90]. In 2010, the International Agency for Research on Cancer (IRAC) classified $\mathrm{TiO}_{2}$ as a human carcinogen in response to sufficient evidence that inhalation of $\mathrm{TiO}_{2}$ nanoparticles promotes lung cancer [94]. In recent decades, many experts in the field expressed their concerns about the safety of $\mathrm{TiO}_{2}$, initiating a re-evaluation of the use of $\mathrm{TiO}_{2}$ nanoparticles as a food additive by the EFSA in 2016. Although the available data were considered insufficient and not of concern, a safety margin of $2.25 \mathrm{mg} \mathrm{TiO} / 2 / \mathrm{kg}_{\mathrm{BW}} /$ day was introduced [90]. In 2018, the discussion was re-opened when the EFSA followed a request from the European Commission to deliver a scientific opinion regarding the safety of $\mathrm{TiO}_{2}$ in food products. With only four publications considered relevant [95-98], the committee concluded that a re-evaluation of the current opinion was not required considering the outcome of the studies [90]. Other valuable studies that indicate severe impacts on human health by consuming $\mathrm{TiO}_{2}$ nanoparticles were neglected [77,92,99-102].

The discussion was recently re-opened, and voices were raised demanding the ban of $\mathrm{TiO}_{2}$ from food. On the first of January 2021, the French government followed a recommendation from the French Agency for Food, Environmental and Occupational Health and Safety (ANSES) to prohibit the sale of all food products containing $\mathrm{TiO}_{2}[103,104]$. In an open letter to the European Commission, more than 26 European and national non- 
governmental organizations called for a general Europe-wide ban of $\mathrm{TiO}_{2}$ in food [105]. By the end of 2020, the European Parliament called on the European Commission to apply the "precautionary principle" and to remove $\mathrm{TiO}_{2}$ from the EU list of permitted food additives [106,107]. A recent reassessment of $\mathrm{TiO}_{2}$ on the part of the EFSA raised severe doubts about the safety of $\mathrm{TiO}_{2}$ as a food additive and consequently resulted in a ban of $\mathrm{TiO}_{2}$ from food products within the EU earlier this year.

\section{4. $\mathrm{TiO}_{2}$ Effects on Gut Homeostasis-New Insights}

$\mathrm{TiO}_{2}$ nanoparticles are heavily used in comestible goods, and exposure can occur via oral uptake, skin contact, or inhalation. Due to their small size, $\mathrm{TiO}_{2}$ nanoparticles penetrate the gastrointestinal barrier [108,109]. For the broad public, the relevant route of $\mathrm{TiO}_{2}$ uptake is ingestion of nanoparticles with the food. $\mathrm{TiO}_{2}$ nanoparticles pass through the GIT following oral uptake, where the food matrix and biopolymers can alter their physicochemical properties, influencing their gastrointestinal fate [110,111].

Currently available data from animal models indicate that the majority of ingested $\mathrm{TiO}_{2}$ nanoparticles is not absorbed into the system but is excreted with the feces [112-116]. A human volunteer study testing different particle sizes $(15 \mathrm{~nm}, 100 \mathrm{~nm}, 5000 \mathrm{~nm})$ did not detect increased $\mathrm{TiO}_{2}$ levels in the serum after single oral $\mathrm{TiO}_{2}$ exposure, independent of the particle size [113]. Strikingly, however, $\mathrm{TiO}_{2}$ nanoparticles were evidenced in human livers and spleens, indicating that they accumulate in the human body [117]. In mouse models, $\mathrm{TiO}_{2}$ accumulation was found in the GIT, brain, blood, liver, spleen, kidneys, heart, and lung tissues after oral longer-term exposure [96,108,109,118-123]. Three pathways for particle translocation from the GIT into the system have been identified so far: paracellular transport across tight junctions, transcytosis across M-cells in Peyer's patches, and persorption across degrading enterocytes [108,124] (Figure 2).

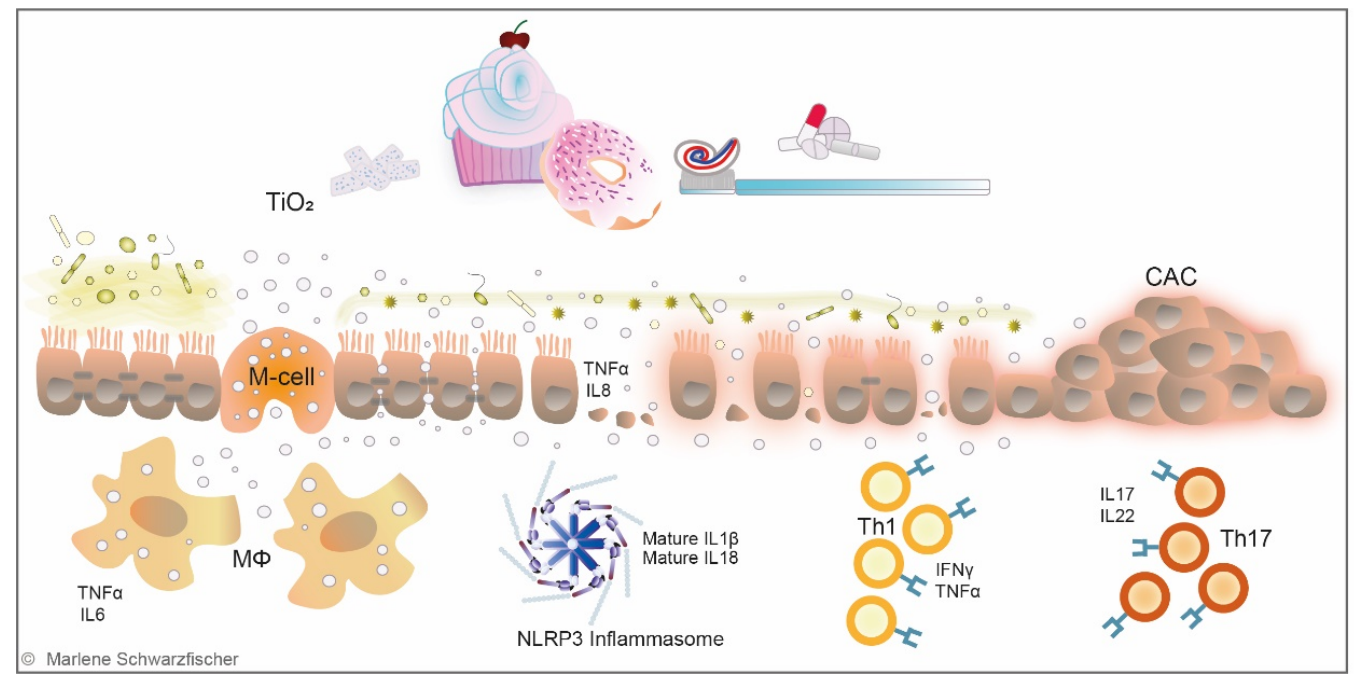

Figure 2. $\mathrm{TiO}_{2}$-impact on gut homeostasis. Food-grade titanium dioxide $\left(\mathrm{TiO}_{2}\right)$ nanoparticles are omnipresent in the Western diet. Ingested $\mathrm{TiO}_{2}$ nanoparticles can enter the system through microfold cells (M-cells), paracellular transport through epithelial cells or penetration through epithelial lesions. In the gut, $\mathrm{TiO}_{2}$ exposure negatively affects microbiota diversity/composition and has adverse impacts on barrier integrity via reduction in mucus secretion, modulation of tight junctions, and induction of pro-inflammatory cytokine expression in enterocytes. $\mathrm{TiO}_{2}$ nanoparticles accumulate in phagocytic macrophages $(\mathrm{M} \phi)$, promoting pro-inflammatory response. Furthermore, $\mathrm{TiO}_{2}$ nanoparticles activate the NLRP3 inflammasome in epithelial and immune cells, triggering proinflammatory signaling cascades. $\mathrm{TiO}_{2}$ exposure induces clonal expansion of T-helper (Th1/Th17) cells in the lamina propria, which exert pro-inflammatory functions and are closely associated with IBD pathogenesis. Together, these events promote chronic epithelial lesions and intestinal inflammation, resulting in an elevated risk of developing colitis-associated colon carcinoma (CAC). 
Following multiple approaches, Brun et al. showed that $\mathrm{TiO}_{2}$ nanoparticles cross the ileum epithelium and Peyer's patches, inducing epithelial impairment and chronic damage [108] (Figure 2). These findings are supported by in vitro studies, showing that $\mathrm{TiO}_{2}$ nanoparticles disrupt tight junctions between intestinal epithelial cells and induce the expression of pro-inflammatory cytokines [125]. Furthermore, it was demonstrated that $\mathrm{TiO}_{2}$ application in vitro and in vivo significantly decreased mucus secretion $[126,127]$ (Figure 2). Interestingly, intestinal biopsies sampled from IBD patients revealed aggregates of $\mathrm{TiO}_{2}$ nanoparticles in M-cells and underlying macrophages of gut-associated lymphoid tissue [128], where the earliest signs of lesions in CD are usually observed [119,129]. Followup studies reported a disruption of systemic or gastrointestinal immune homeostasis and microbiota dysbiosis upon $\mathrm{TiO}_{2}$ administration [96,130-132]. Li et al. were the first to associate $\mathrm{TiO}_{2}$ with the gut microbiome [131]. In line with these findings, Mu et al. and Pinget et al. reported microbiota dysbiosis and altered release of bacterial metabolites following $\mathrm{TiO}_{2}$ intake $[130,132]$ (Figure 2). Nogueria et al. were the first to describe Th1mediated inflammatory response in the small intestine of mice orally treated with $\mathrm{TiO}_{2}$ nanoparticles [133]. Bettini et al. observed an exceeding Th1/Th17 immune response in the Peyer's patches from rats orally exposed to $\mathrm{TiO}_{2}$, resembling Th17-driven autoimmune diseases in humans [96] (Figure 2). Talamini et al. reported intestinal inflammation upon $\mathrm{TiO}_{2}$ exposure $[120,132]$. Recent studies revealed dysfunction of the epithelial barrier in the ileum, probably induced by a Th1/Th2 imbalance and/or increased lipopolysaccharide (LPS) signaling upon $\mathrm{TiO}_{2}$ administration $[134,135]$. Studies performed by Huang et al. indicate that $\mathrm{TiO}_{2}$ nanoparticles prime an abnormal activation state of macrophages, characterized by an excessive pro-inflammatory phenotype and suppressed innate immune function [136]. Furthermore, $\mathrm{TiO}_{2}$ nanoparticles were shown to cause mitochondrial dysfunction, induce oxidative stress and attenuate phagocytotic capacities of macrophages [136]. In 2017, our group detected increased $\mathrm{TiO}_{2}$ serum levels in $\mathrm{UC}$ patients undergoing an acute phase of the disease. Oral administration of $\mathrm{TiO}_{2}$ nanoparticles in a mouse model of acute DSS-induced colitis triggered assembly of the NLR pyrin domain-containing 3 (NLRP3) inflammasome and release of the pro-inflammatory cytokines interleukin (IL)-1 $\beta$ and IL-18 resulted in aggravation of intestinal inflammation [119]. In line with these findings, Mu et al. described an aggravation of chronic DSS colitis and reduced CD4+ T-cells and Tregs populations in mesenteric lymph nodes (MLN) [130]. Contrary, in a very recent study from Gao et al. $\mathrm{TiO}_{2}$ administration ameliorated Trinitrobenzenesulfonic acid solution (TNBS)-induced colitis. The authors describe that $\mathrm{TiO}_{2}$ nanoparticles decreased TNF expression in the colon and beneficially modified the microbiome, including depletion of pathogenic commensal strains [137].

In addition to their IBD promoting potential, food-grade $\mathrm{TiO}_{2}$ nanoparticles were shown to exacerbate tumor formation in the DSS azoxymethane (AOM) [138] and the dimethylhydrazine (DHM) colon cancer model [96]. IBD with colonic involvement predisposes patients to develop colitis-associated cancer (CAC) due to the chronic inflammatory state [139-142]. It has been reported that CD increases the risk of developing colorectal cancer (CRC) by roughly 1.8 times and UC even up to 8 times compared to the risk of developing CRC in the general population [143]. CAC represents about $2 \%$ of all CRC cases [144], and it has been extensively reported that patients with IBD who develop CAC are frequently diagnosed at an advanced stage and face a worse prognosis than those with CRC without IBD [145-148].

Ingestion of $\mathrm{TiO}_{2}$ nanoparticles causes impairment of innate and adaptive immune system, microbial dysbiosis, and breakdown of the intestinal epithelial barrier-characteristic key events of IBD pathogenesis. Chronic dietary exposure with $\mathrm{TiO}_{2}$ nanoparticles may disrupt intestinal homeostasis and low-grade inflammation in healthy individuals. In IBD patients, translocation of $\mathrm{TiO}_{2}$ nanoparticles might be substantially increased due to disruption of the intestinal barrier, causing an amplification of these processes and exacerbation of inflammation. Therefore, food-grade $\mathrm{TiO}_{2}$ nanoparticles might be an underrated IBD trigger and a potential risk for healthy individuals and patients suffering from intestinal 
diseases. Since $\mathrm{TiO}_{2}$ nanoparticles in food and comestible goods only serve the purpose of increasing the appeal and the commercial value of certain products, this health risk seems unnecessary and unreasonable. By the first of January in 2022, $\mathrm{TiO}_{2}$ was banned as a food additive by the European parliament. However, it is still present in cosmetic products, such as toothpaste, or pharmacological preparations, such as tablets or pills.

\section{Global Plastic Crisis-Intestinal Consequences?}

Apart from food additives, plastic particles are also consumed unknowingly with our diet. After decades of environmental pollution with plastic products of all kinds and shapes, concerns are rising that this global load of plastic might impact marine and terrestrial life. Nonetheless, production volume and consumption are continuously expanding [149], and the accumulation of plastic debris is increasing all over the planet [150,151]. The most commonly used plastic polymers are low-density polyethylene (LDPE), high-density polyethylene (HDPE), polypropylene (PP), polystyrene (PS), polyethylene terephthalate (PET), and polyvinyl chloride (PVC). In contrast, other polymers, such as nylon, acrylic, polyurethanes, polylactic acid, polycarbonate, and other plastics are also present [152]. By 2019, 368 million tons of plastic had been produced [149], of which approximately more than 8 million metric tons are entering the oceans every year [151].

Attention is mainly directed on small plastic particles. Primary plastic particles are introduced to fresh and saltwater as manufactured micro-scale polymers in cosmetic care products or medicine [153-155]. In contrast, secondary particles emerge due to progressing fragmentation of plastic litter [156,157] (Figure 3). A substantial part of secondary plastic particles derives from public trash, inadequate waste disposal by the fishing industry [158], and sewage water containing plastic particles generated from washing synthetic textiles [159] or tire abrasion [160] (Figure 3). Environmental impacts, including UV radiation, mechanical forces, biological degradation, and embrittlement, result in the formation of so-called microplastic (MP) particles with diameters $<5 \mathrm{~mm}[161,162]$. These microplastic particles can be further fragmented into nanoplastic (NP) particles (Figure 3). The exact definition of NP is currently controversially discussed. MP particles have been discovered all over the globe, including beaches, shores, fresh and salt water, deep-sea sediments, and even in the Antarctic sea ice [154]. The load of MP debris in the oceans may differ geographically [152]

The effects of NP and MP exposure on aquatic organisms have been intensively studied. MP particles were shown to cause oxidative stress, epithelial damage, intestinal inflammation, and consecutive mortality in zebrafish Danio rerio $[163,164]$. Furthermore, MP exposure impacts the energy homeostasis of marine species by reducing energy intake due to decreased feeding activity, reduced predatory performance, and adverse effects on digestion, such as inhibition of digestive enzymes and therefore impaired uptake of nutrients [165-170]. Moreover, MP ingestion resulted in a negative energy balance due to increased energy consumption, resulting from inflammatory response, increased gut residence time and excretion mechanisms [165,166,168,169], and metabolic changes [170-172]. In mussels, MP exposure resulted in immunosuppression and tissue-dependent modulation of the immune response [173,174].

NP and MP exposure occurs via inhalation, ingestion, or dermal contact. Washing and shedding synthetic textiles abrasion of tires and commodities generates air-born NP and MP particles, small enough to enter the respiratory tract $[166,175]$. Prata et al. estimated that human beings inhale 26-130 MP particles per day [176], while studies by Vianello et al. suggested an average intake of $272 \mathrm{MP}$ particles a day [177]. Respiratory uptake of MP particles might be even higher in individuals working in synthetic textile, flocks, and the vinyl chloride or polyvinyl chloride industries, where respiratory diseases among the workers are frequently described [178,179]. In 1998, Pauly et al. evidenced plastic fibers in human lung and lung cancer biopsies [180]. In rat models, intratracheal exposure resulted in biochemical and histopathological changes of rat lungs due to acute inflammatory response [181,182]. 


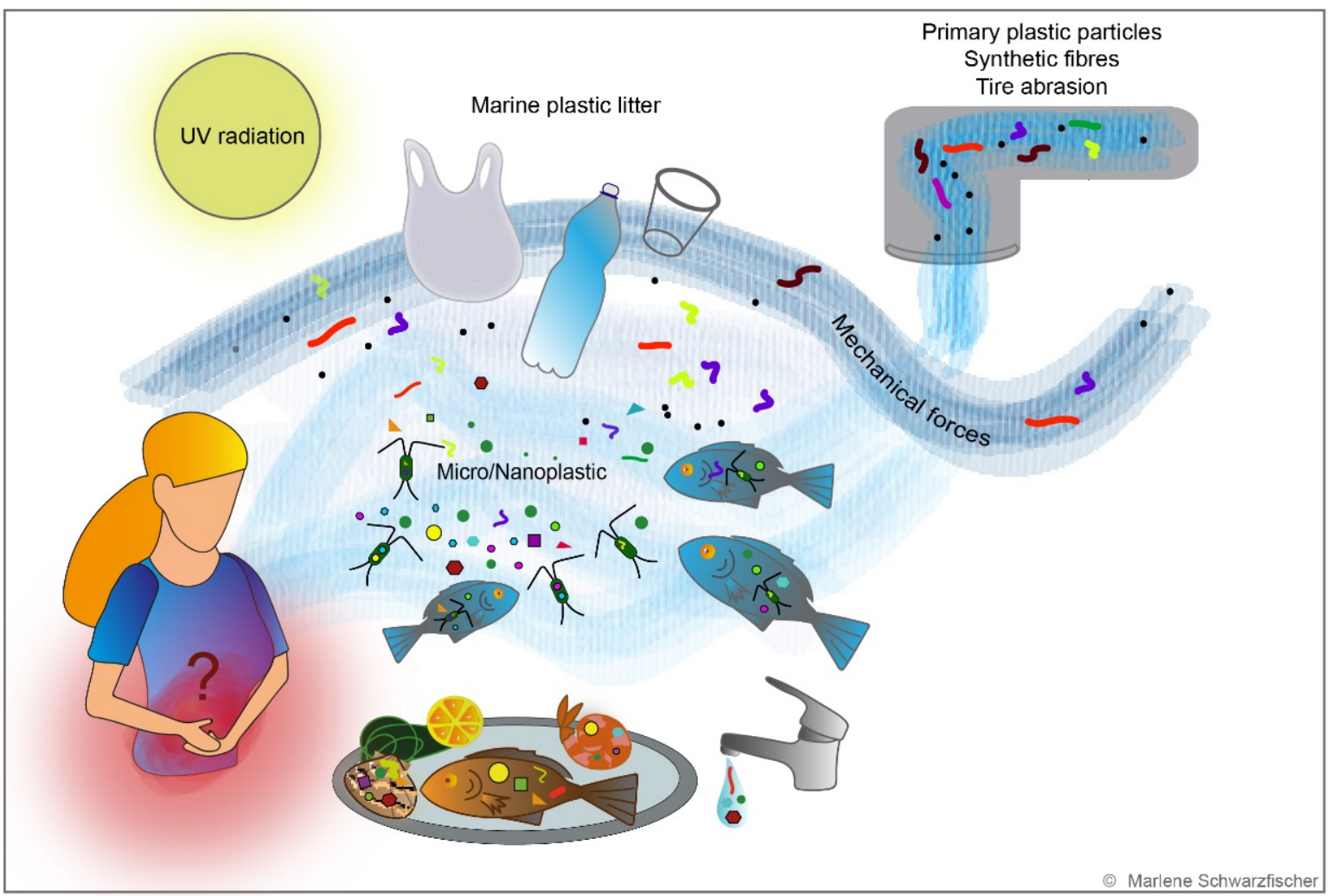

Figure 3. Nano- and microplastics in the environment. Several sources contribute to plastic contamination of fresh and salt water. Primary MP particles are designed for commercial use and encountered in cosmetic and pharmaceutical products. In contrast, secondary MP plastic particles progressively emerge with plastic fragmentation under the influence of environmental conditions. UV radiation, mechanical forces, biological degradation, and embrittlement result in the formation of NP and MP particles, which are ingested by marine zooplankton and consequently enter the marine and human food chain. Microplastic contamination was evidenced in seafood, drinking water, and other foodstuff. However, the impacts of ingested plastic particles on human health are not yet understood.

Ingestion is considered the primary route of human plastic exposure [183]. It is estimated that, on average, an adult person consumes around 39,000-52,000 particles a year [184] or $5 \mathrm{~g}$ of plastic every week [185] — the equivalent of a credit card. In addition, MP has been evidenced in human feces [186] and all human organs [187]. Although most studies investigating the effect of plastic particles on the environment have been conducted in the marine ecosystem, plastic contamination might be more pervasive in the terrestrial ecosystem and human diet than expected. Small plastic particles are ingested by aquatic organisms, enter the circulatory system of marine wildlife [163,188-192], and then spread throughout the marine food chain, contaminating seafood which ends up on the markets for human consumption [193-195] (Figure 3). Although plastic packaging for drinks and food is an obvious source of ingested NP and MP particles [196-199], MP particles have also been found in tap water, honey, sugar, sea salt, and beer [200-204].

So far, the absorption and translocation of NP and MP particles in the human body have not been thoroughly investigated. However, it is likely that due to their similar size and chemical inertness, plastic particles take the same routes as $\mathrm{TiO}_{2}$ nanoparticles [124]. Plastic research is still in its infancy, and the impact of NP and MP exposure on human health is hardly predictable. The toxicity of plastic particles might depend on their chemical composition and is assumed to have a dose-dependent, accumulative effect [73,74]. In vitro studies demonstrated that human immune cells and intestinal and lung epithelial cells internalize MP particles, which results in oxidative stress, endoplasmatic reticulum (ER) stress, and autophagic cell death $[32,205,206]$. Plastic was shown to accumulate in the liver, 
kidney, and gut of mice fed with MP particles [29,171]. Several studies describe adverse health effects in rodents orally exposed to MP particles.

Very little data are available on NP particles, although they may possess increased bioactivity due to their small size. Deng et al. were the first to describe the accumulation of MP particles in the liver, kidney, and the GIT and its impacts on energy and lipid metabolism, oxidative stress, and neurotoxicity caused by PS MP particles [171]. However, this study was critically discussed $[207,208]$. A follow-up study described adverse impacts of PS particles on the reproductive system of male mice caused by oxidative stress and activation of mitogen-activated protein kinase (MAPK) P38 [209]. This study was supported by Hou et al., Park et al., and Haibo et al. describing reproductive and developmental toxicity of PS [210,211] and PE particles [210]. Furthermore, Hou et al. reported adverse effects of PS MP on the ovary of mice, potentially resulting in female infertility [212]. Luo et al. exposed pregnant mice to PS MP particles and observed metabolic disorders in their offspring, indicating that MP particles might cross the placenta [213]. Luo et al. reported altered metabolic homeostasis in the offspring of PS MP exposed mice [214]. In a physiological approach by Preia de Costa Araújo and Malafaia, tadpoles were exposed to MP particles, fed to fish, and plastic-contaminated fish were fed to experimental mice. MP was found to accumulate in tadpoles, fish, and mice, proving translocation of MP from the aquatic to the terrestrial food chain. Furthermore, MP was shown to induce behavioral disorders in mice [215]. Overall, the impact of MP particles on rodents was relatively mild compared to the effects of MP exposure in aquatic species. Discrepancies between rodents and fish might result from anatomical differences, whereby fish gills allow multiple routes for plastic uptake and accumulation. In contrast, plastic uptake in rodents is limited to the gastrointestinal route [216].

The impact of small plastic particles on intestinal health is controversially discussed and different in vivo mouse experiments obtained contradictory results. So far, only a few studies-using different types and sizes of plastic and various exposure timesinvestigating the impact of plastic particles on the gut have been conducted (Table 1). Lu et al. reported that oral plastic exposure induced hepatic lipid disorder in mice. Furthermore, they detected alterations in mucus secretion and changes in the richness and diversity of the gut microbiota characterized by a decrease in relative abundances of Firmicutes and $\alpha$-Proteobacteria [28] (Figure 4). Jin et al. described the breakdown of the epithelial barrier, gut microbiota dysbiosis, and impacts on the metabolic pathways in the microbial community in mice treated with MP particles [29] (Figure 4). At the same time, Li et al. [30] and Qiao et al. [217] characterized similar effects upon treatment with MP particles (Figure 4). Strikingly, Zheng et al. reported that MP administration aggravated acute DSS colitis and increased intestinal epithelial permeability [31]. Controversially, Stock et al. did not detect histological changes or inflammatory response in the intestine after exposure to MP particles [32] (Figure 4). Within our work we investigated the effect of plastic nanoparticles on intestinal health and evaluated their inflammatory potential in acute and chronic models of colitis. Surprisingly, in vivo experiments performed by our group did not reveal adverse effects on gastrointestinal health nor gut inflammation. Although, we evidenced NP and MP the system, long-term administration of nano- or micro-sized PS particles did not alter gut homeostasis, nor did it promote acute or chronic DSS colitis [218] (Figure 4). Nevertheless, our data align with previous studies, reporting an accumulation of ingested plastic particles in organs distant from the gut [29,175]. Limiting our study to a colonic IBD model, we cannot exclude the potential effects of plastic ingestion on the small intestine, primarily affected in CD [219].

Consumption of small plastic particles is rising with the increasing abundance of plastic in the human diet and toxicity might be increasing with an accumulation of plastic particles in the body. Therefore, studying the effects of plastic exposure on human health is of great interest. IBD patients might be particularly vulnerable to the adverse effects of ingested plastic particles as disruption, and increased permeability of the intestinal epithelial barrier [220] might enable translocation of NP and MP particles to a greater 
extent. However, a potential disease-promoting effect of plastic particles in IBD requires further investigation.

Table 1. Literature Search: Impact of NP and MP on intestinal health of rodents.

\begin{tabular}{cccccc}
\hline Publication & Type & Size & Dose & \multicolumn{2}{c}{ Administration } \\
\hline Lu 2018 [28] & PS & $0.5 \mu \mathrm{m}$ and $50 \mu \mathrm{m}$ & $100,1000 \mu \mathrm{g} / \mathrm{L}$ & Drinking water & Continuous $5 \mathrm{w}$ \\
\hline Jin 2019 [29] & PS & $5 \mu \mathrm{m}$ & $1000 \mathrm{ug} / \mathrm{L}$ & Drinking water & Continuous $6 \mathrm{w}$ \\
\hline Stock 2019 [32] & PS & Mixture: $1,4,10 \mu \mathrm{m}$ & $10 \mathrm{~mL} / \mathrm{kg}$ BW & Gavage & $3 \times$ per week $4 \mathrm{w}$ \\
\hline Li 2020 [30] & PE & Mixture: $10-150 \mu \mathrm{m}$ & $6,60,600 \mu \mathrm{g} /$ day & Drinking water & Continuous $5 \mathrm{w}$ \\
\hline Zheng 2021 [31] & PS & $5 \mu \mathrm{m}$ & $500 \mathrm{ug} / \mathrm{L}$ & Drinking water & Continuous $4 \mathrm{w}$ \\
\hline Qiao 2021 [217] & PS & $70 \mathrm{~nm}$ and $5 \mu \mathrm{m}$ & $0.2 \mathrm{or} 2 \mathrm{mg} / \mathrm{kg} \mathrm{BW}$ & Gavage & $1 \times$ per day $4 \mathrm{w}$ \\
\hline Schwarzfischer 2021 [218] & PS & $50 \mathrm{~nm}$ and $1 \mu \mathrm{m}$ & $0.2 \mathrm{mg} /$ day & Drinking water & Continuous $24 \mathrm{w}$ \\
\hline
\end{tabular}

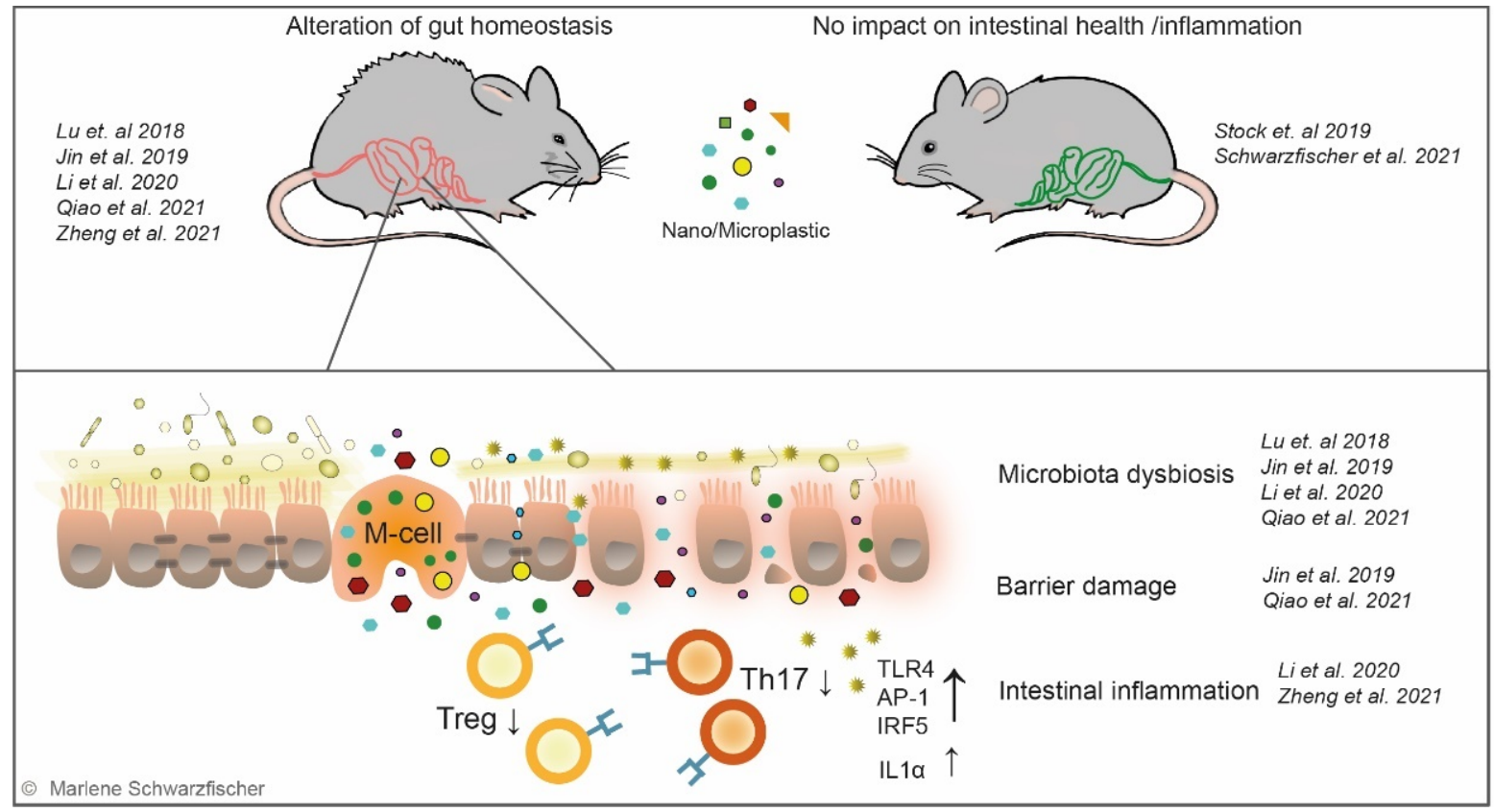

Figure 4. Nano- and microplastics-impact on gut homeostasis. The impact of nano- and micro-sized plastic particles on the intestine is controversially discussed, and the number of studies investigating these relations is limited. It is assumed that small plastic particles take the same routes as $\mathrm{TiO}_{2}$ nanoparticles and penetrate the intestinal epithelium. Although two publications did not detect any effects of NP or MP on intestinal health and/or inflammation, respectively, conflicting studies report alteration of the gut homeostasis upon plastic administration in mouse models. Several studies describe adverse effects on the gut microbiome, reduced mucus secretion, and damage of barrier integrity upon administration of MP particles. Li et al. describe the reduction in regulatory T-cells (Treg) and Th17 cells, increased Toll-like receptor 4 (TLR4) downstream signaling, and IL1 $\alpha$ expression, suggesting activation of pro-inflammatory cascades and translocation of bacterial products into the system $[28-32,217,218]$.

\section{Summary}

The presence of nano-and microparticles in the human diet has recently gained public awareness and raised significant concerns. Their impact on human health is not yet fully understood and controversially discussed. Although $\mathrm{TiO}_{2}$ nanoparticles, designated as food-coloring agent E171, are systematically applied to food products for cosmetic reasons, plastic particles in drinking water and food stuff are the consequence of longstanding 
environmental pollution. Breakdown of the intestinal epithelial barrier and aberrant immune responses are key events in the pathogenesis of IBD. Epithelial lesions might enable translocation of particles into the system, where they might trigger an excessive immune response. Therefore, IBD patients might be particularly vulnerable to adverse health effects caused by the ingestion of nano- and microparticles.

Just recently, the European Union took action and banned $\mathrm{TiO}_{2}$ nanoparticles from food production-a decision which was built upon a body of literature, raising serious doubts about the safety of food-grade $\mathrm{TiO}_{2}$. With respect to intestinal diseases, several good studies demonstrated the inflammatory potential of $\mathrm{TiO}_{2}$ nanoparticles and reported negative impacts on the intestinal barrier and the gut microbiome. Although the scientific evidence on the harmful properties of $\mathrm{TiO}_{2}$ nanoparticles seems to be explicit, the process of understanding the effects of dietary nano- and microplastic particles on the human body is still at the very beginning. The impacts of plastic particles on epithelial integrity, gut homeostasis, and intestinal inflammation are controversially discussed and require further investigation.

Author Contributions: Conceptualization, G.R.; resources, G.R.; writing—original draft preparation, M.S. and G.R.; writing — review and editing, M.S. and G.R.; visualization, M.S.; funding acquisition, G.R. All authors have read and agreed to the published version of the manuscript.

Funding: This research was funded by Swiss National Foundation (SNF), Grant No. 324730_170109: "Dietary nanoparticles and their impact on Inflammatory Bowel Disease pathogenesis-Large Nested Project within the SWISS IBD Cohort Study".

Acknowledgments: We would like to thank for the project support by Marianne Spalinger and Michael Scharl.

Conflicts of Interest: The authors declare no conflict of interest.

\section{References}

1. Furuse, M.; Sasaki, H.; Fujimoto, K.; Tsukita, S. A single gene product, claudin-1 or -2, reconstitutes tight junction strands and recruits occludin in fibroblasts. J. Cell Biol. 1998, 143, 391-401. [CrossRef] [PubMed]

2. Tsukita, S.; Furuse, M.; Itoh, M. Multifunctional strands in tight junctions. Nat. Rev. Mol. Cell Biol. 2001, 2, 285-293. [CrossRef] [PubMed]

3. Furuse, M.; Hirase, T.; Itoh, M.; Nagafuchi, A.; Yonemura, S.; Tsukita, S.; Tsukita, S. Occludin: A novel integral membrane protein localizing at tight junctions. J. Cell Biol. 1993, 123, 1777-1788. [CrossRef] [PubMed]

4. Berin, M.C.; Li, H.; Sperber, K. Antibody-mediated antigen sampling across intestinal epithelial barriers. Ann. N. Y. Acad. Sci. 2006, 1072, 253-261. [CrossRef]

5. Schneeberger, E.E.; Lynch, R.D. The tight junction: A multifunctional complex. Am. J. Physiol. Cell Physiol. 2004, 286, C1213-C1228. [CrossRef] [PubMed]

6. Chassaing, B.; Aitken, J.D.; Malleshappa, M.; Vijay-Kumar, M. Dextran sulfate sodium (DSS)-induced colitis in mice. Curr. Protoc. Immunol. 2014, 104, 15.25.1-15.25.14. [CrossRef] [PubMed]

7. Rogler, G.; Biedermann, L.; Scharl, M. New insights into the pathophysiology of inflammatory bowel disease: Microbiota, epigenetics and common signalling pathways. Swiss Med. Wkly. 2018, 148, w14599. [CrossRef] [PubMed]

8. Rogler, G.; Vavricka, S. Exposome in IBD: Recent insights in environmental factors that influence the onset and course of IBD. Inflamm. Bowel Dis. 2015, 21, 400-408. [CrossRef] [PubMed]

9. Guan, Q. A Comprehensive Review and Update on the Pathogenesis of Inflammatory Bowel Disease. J. Immunol. Res. 2019, 2019, 7247238. [CrossRef]

10. Ince, M.N.; Elliott, D.E. Immunologic and molecular mechanisms in inflammatory bowel disease. Surg. Clin. N. Am. 2007, 87, 681-696. [CrossRef]

11. Hollander, D. Permeability in Crohn's disease: Altered barrier functions in healthy relatives? Gastroenterology 1993, 104, 1848-1851. [CrossRef]

12. Turpin, W.; Lee, S.H.; Raygoza Garay, J.A.; Madsen, K.L.; Meddings, J.B.; Bedrani, L.; Power, N.; Espin-Garcia, O.; Xu, W.; Smith, M.I.; et al. Increased Intestinal Permeability Is Associated With Later Development of Crohn's Disease. Gastroenterology 2020, 159, 2092-2100.e5. [CrossRef] [PubMed]

13. Schmitz, H.; Barmeyer, C.; Fromm, M.; Runkel, N.; Foss, H.D.; Bentzel, C.J.; Riecken, E.O.; Schulzke, J.D. Altered tight junction structure contributes to the impaired epithelial barrier function in ulcerative colitis. Gastroenterology 1999, 116, 301-309. [CrossRef]

14. Gitter, A.H.; Wullstein, F.; Fromm, M.; Schulzke, J.D. Epithelial barrier defects in ulcerative colitis: Characterization and quantification by electrophysiological imaging. Gastroenterology 2001, 121, 1320-1328. [CrossRef] [PubMed] 
15. Marin, M.L.; Geller, S.A.; Greenstein, A.J.; Marin, R.H.; Gordon, R.E.; Aufses, A.H., Jr. Ultrastructural pathology of Crohn's disease: Correlated transmission electron microscopy, scanning electron microscopy, and freeze fracture studies. Am. J. Gastroenterol. 1983, 78, 355-364. [PubMed]

16. Marin, M.L.; Greenstein, A.J.; Geller, S.A.; Gordon, R.E.; Aufses, A.H., Jr. A freeze fracture study of Crohn's disease of the terminal ileum: Changes in epithelial tight junction organization. Am. J. Gastroenterol. 1983, 78, 537-547. [PubMed]

17. Zeissig, S.; Burgel, N.; Gunzel, D.; Richter, J.; Mankertz, J.; Wahnschaffe, U.; Kroesen, A.J.; Zeitz, M.; Fromm, M.; Schulzke, J.D. Changes in expression and distribution of claudin 2, 5 and 8 lead to discontinuous tight junctions and barrier dysfunction in active Crohn's disease. Gut 2007, 56, 61-72. [CrossRef]

18. Gitter, A.H.; Bendfeldt, K.; Schulzke, J.D.; Fromm, M. Leaks in the epithelial barrier caused by spontaneous and TNF-alphainduced single-cell apoptosis. FASEB J. 2000, 14, 1749-1753. [CrossRef] [PubMed]

19. Bojarski, C.; Gitter, A.H.; Bendfeldt, K.; Mankertz, J.; Schmitz, H.; Wagner, S.; Fromm, M.; Schulzke, J.D. Permeability of human HT-29/B6 colonic epithelium as a function of apoptosis. J. Physiol. 2001, 535, 541-552. [CrossRef] [PubMed]

20. Kucharzik, T.; Maaser, C.; Lugering, A.; Kagnoff, M.; Mayer, L.; Targan, S.; Domschke, W. Recent understanding of IBD pathogenesis: Implications for future therapies. Inflamm. Bowel Dis. 2006, 12, 1068-1083. [CrossRef] [PubMed]

21. Nusrat, A.; Turner, J.R.; Madara, J.L. Molecular physiology and pathophysiology of tight junctions. IV. Regulation of tight junctions by extracellular stimuli: Nutrients, cytokines, and immune cells. Am. J. Physiol. Gastrointest. Liver Physiol. 2000, 279, G851-G857. [CrossRef]

22. Bruewer, M.; Luegering, A.; Kucharzik, T.; Parkos, C.A.; Madara, J.L.; Hopkins, A.M.; Nusrat, A. Proinflammatory cytokines disrupt epithelial barrier function by apoptosis-independent mechanisms. J. Immunol. 2003, 171, 6164-6172. [CrossRef]

23. Lei, H.; Crawford, M.S.; McCole, D.F. JAK-STAT Pathway Regulation of Intestinal Permeability: Pathogenic Roles and Therapeutic Opportunities in Inflammatory Bowel Disease. Pharmaceuticals 2021, 14, 840. [CrossRef] [PubMed]

24. Power, N.; Turpin, W.; Espin-Garcia, O.; Smith, M.I.; Consortium, C.G.P.R.; Croitoru, K. Serum Zonulin Measured by Commercial Kit Fails to Correlate With Physiologic Measures of Altered Gut Permeability in First Degree Relatives of Crohn's Disease Patients. Front. Physiol. 2021, 12, 645303. [CrossRef]

25. Lee, S.H.; Turpin, W.; Espin-Garcia, O.; Raygoza Garay, J.A.; Smith, M.I.; Leibovitzh, H.; Goethel, A.; Turner, D.; Mack, D.; Deslandres, C.; et al. Anti-Microbial Antibody Response is Associated With Future Onset of Crohn's Disease Independent of Biomarkers of Altered Gut Barrier Function, Subclinical Inflammation, and Genetic Risk. Gastroenterology 2021, 161, 1540-1551. [CrossRef] [PubMed]

26. Wild, C.P. Complementing the genome with an "exposome": The outstanding challenge of environmental exposure measurement in molecular epidemiology. Cancer. Epidemiol. Biomarkers Prev. 2005, 14, 1847-1850. [CrossRef]

27. Abegunde, A.T.; Muhammad, B.H.; Bhatti, O.; Ali, T. Environmental risk factors for inflammatory bowel diseases: Evidence based literature review. World J. Gastroenterol. 2016, 22, 6296-6317. [CrossRef]

28. Lu, L.; Wan, Z.; Luo, T.; Fu, Z.; Jin, Y. Polystyrene microplastics induce gut microbiota dysbiosis and hepatic lipid metabolism disorder in mice. Sci. Total Environ. 2018, 631-632, 449-458. [CrossRef] [PubMed]

29. Jin, Y.; Lu, L.; Tu, W.; Luo, T.; Fu, Z. Impacts of polystyrene microplastic on the gut barrier, microbiota and metabolism of mice. Sci. Total Environ. 2019, 649, 308-317. [CrossRef] [PubMed]

30. Li, B.; Ding, Y.; Cheng, X.; Sheng, D.; Xu, Z.; Rong, Q.; Wu, Y.; Zhao, H.; Ji, X.; Zhang, Y. Polyethylene microplastics affect the distribution of gut microbiota and inflammation development in mice. Chemosphere 2020, 244, 125492. [CrossRef] [PubMed]

31. Zheng, H.; Wang, J.; Wei, X.; Chang, L.; Liu, S. Proinflammatory properties and lipid disturbance of polystyrene microplastics in the livers of mice with acute colitis. Sci. Total Environ. 2021, 750, 143085. [CrossRef] [PubMed]

32. Stock, V.; Bohmert, L.; Lisicki, E.; Block, R.; Cara-Carmona, J.; Pack, L.K.; Selb, R.; Lichtenstein, D.; Voss, L.; Henderson, C.J.; et al. Uptake and effects of orally ingested polystyrene microplastic particles in vitro and in vivo. Arch. Toxicol. 2019, 93, 1817-1833. [CrossRef]

33. Ananthakrishnan, A.N.; McGinley, E.L.; Binion, D.G.; Saeian, K. Ambient air pollution correlates with hospitalizations for inflammatory bowel disease: An ecologic analysis. Inflamm. Bowel Dis. 2011, 17, 1138-1145. [CrossRef] [PubMed]

34. Kaplan, G.G.; Hubbard, J.; Korzenik, J.; Sands, B.E.; Panaccione, R.; Ghosh, S.; Wheeler, A.J.; Villeneuve, P.J. The inflammatory bowel diseases and ambient air pollution: A novel association. Am. J. Gastroenterol. 2010, 105, 2412-2419. [CrossRef] [PubMed]

35. Opstelten, J.L.; Beelen, R.M.J.; Leenders, M.; Hoek, G.; Brunekreef, B.; van Schaik, F.D.M.; Siersema, P.D.; Eriksen, K.T.; RaaschouNielsen, O.; Tjonneland, A.; et al. Exposure to Ambient Air Pollution and the Risk of Inflammatory Bowel Disease: A European Nested Case-Control Study. Dig. Dis. Sci. 2016, 61, 2963-2971. [CrossRef] [PubMed]

36. Salim, S.Y.; Kaplan, G.G.; Madsen, K.L. Air pollution effects on the gut microbiota: A link between exposure and inflammatory disease. Gut Microbes 2014, 5, 215-219. [CrossRef]

37. Beamish, L.A.; Osornio-Vargas, A.R.; Wine, E. Air pollution: An environmental factor contributing to intestinal disease. J. Crohns Colitis 2011, 5, 279-286. [CrossRef]

38. Masuyama, H.; Hiramatsu, Y.; Kunitomi, M.; Kudo, T.; MacDonald, P.N. Endocrine disrupting chemicals, phthalic acid and nonylphenol, activate Pregnane X receptor-mediated transcription. Mol. Endocrinol. 2000, 14, 421-428. [CrossRef]

39. Soares, A.; Guieysse, B.; Jefferson, B.; Cartmell, E.; Lester, J.N. Nonylphenol in the environment: A critical review on occurrence, fate, toxicity and treatment in wastewaters. Environ. Int. 2008, 34, 1033-1049. [CrossRef] 
40. Vedani, A.; Smiesko, M.; Spreafico, M.; Peristera, O.; Dobler, M. VirtualToxLab-in silico prediction of the toxic (endocrinedisrupting) potential of drugs, chemicals and natural products. Two years and 2,000 compounds of experience: A progress report. ALTEX 2009, 26, 167-176. [CrossRef]

41. Wagner, M.; Schlusener, M.P.; Ternes, T.A.; Oehlmann, J. Identification of putative steroid receptor antagonists in bottled water: Combining bioassays and high-resolution mass spectrometry. PLoS ONE 2013, 8, e72472. [CrossRef] [PubMed]

42. Wark, G.; Samocha-Bonet, D.; Ghaly, S.; Danta, M. The Role of Diet in the Pathogenesis and Management of Inflammatory Bowel Disease: A Review. Nutrients 2020, 13, 135. [CrossRef] [PubMed]

43. David, L.A.; Maurice, C.F.; Carmody, R.N.; Gootenberg, D.B.; Button, J.E.; Wolfe, B.E.; Ling, A.V.; Devlin, A.S.; Varma, Y.; Fischbach, M.A.; et al. Diet rapidly and reproducibly alters the human gut microbiome. Nature 2014, 505, 559-563. [CrossRef] [PubMed]

44. Glassner, K.L.; Abraham, B.P.; Quigley, E.M.M. The microbiome and inflammatory bowel disease. J. Allergy Clin. Immunol. 2020, 145, 16-27. [CrossRef] [PubMed]

45. Limdi, J.K. Dietary practices and inflammatory bowel disease. Indian J. Gastroenterol. 2018, 37, 284-292. [CrossRef]

46. Reddavide, R.; Rotolo, O.; Caruso, M.G.; Stasi, E.; Notarnicola, M.; Miraglia, C.; Nouvenne, A.; Meschi, T.; De' Angelis, G.L.; Di Mario, F.; et al. The role of diet in the prevention and treatment of Inflammatory Bowel Diseases. Acta Biomed. 2018, 89, 60-75. [CrossRef] [PubMed]

47. Levine, A.; Wine, E.; Assa, A.; Sigall Boneh, R.; Shaoul, R.; Kori, M.; Cohen, S.; Peleg, S.; Shamaly, H.; On, A.; et al. Crohn's Disease Exclusion Diet Plus Partial Enteral Nutrition Induces Sustained Remission in a Randomized Controlled Trial. Gastroenterology 2019, 157, 440-450.e8. [CrossRef] [PubMed]

48. Levine, A.; Sigall Boneh, R.; Wine, E. Evolving role of diet in the pathogenesis and treatment of inflammatory bowel diseases. Gut 2018, 67, 1726-1738. [CrossRef]

49. Wagenaar, C.A.; van de Put, M.; Bisschops, M.; Walrabenstein, W.; de Jonge, C.S.; Herrema, H.; van Schaardenburg, D. The Effect of Dietary Interventions on Chronic Inflammatory Diseases in Relation to the Microbiome: A Systematic Review. Nutrients 2021, 13, 208. [CrossRef]

50. Ananthakrishnan, A.N.; Khalili, H.; Konijeti, G.G.; Higuchi, L.M.; de Silva, P.; Korzenik, J.R.; Fuchs, C.S.; Willett, W.C.; Richter, J.M.; Chan, A.T. A prospective study of long-term intake of dietary fiber and risk of Crohn's disease and ulcerative colitis. Gastroenterology 2013, 145, 970-977. [CrossRef]

51. Li, M.; Weigmann, B. A Novel Pathway of Flavonoids Protecting against Inflammatory Bowel Disease: Modulating Enteroendocrine System. Metabolites 2022, 12, 31. [CrossRef] [PubMed]

52. Ballegaard, M.; Bjergstrom, A.; Brondum, S.; Hylander, E.; Jensen, L.; Ladefoged, K. Self-reported food intolerance in chronic inflammatory bowel disease. Scand. J. Gastroenterol. 1997, 32, 569-571. [CrossRef] [PubMed]

53. Andersen, V.; Olsen, A.; Carbonnel, F.; Tjonneland, A.; Vogel, U. Diet and risk of inflammatory bowel disease. Dig. Liver Dis. 2012, 44, 185-194. [CrossRef] [PubMed]

54. Rashvand, S.; Somi, M.H.; Rashidkhani, B.; Hekmatdoost, A. Dietary protein intakes and risk of ulcerative colitis. Med. J. Islam. Repub. Iran. 2015, 29, 253. [PubMed]

55. Kostovcikova, K.; Coufal, S.; Galanova, N.; Fajstova, A.; Hudcovic, T.; Kostovcik, M.; Prochazkova, P.; Jiraskova Zakostelska, Z.; Cermakova, M.; Sediva, B.; et al. Diet Rich in Animal Protein Promotes Pro-inflammatory Macrophage Response and Exacerbates Colitis in Mice. Front. Immunol. 2019, 10, 919. [CrossRef] [PubMed]

56. Hou, J.K.; Abraham, B.; El-Serag, H. Dietary intake and risk of developing inflammatory bowel disease: A systematic review of the literature. Am. J. Gastroenterol. 2011, 106, 563-573. [CrossRef]

57. Chapman-Kiddell, C.A.; Davies, P.S.; Gillen, L.; Radford-Smith, G.L. Role of diet in the development of inflammatory bowel disease. Inflamm. Bowel Dis. 2010, 16, 137-151. [CrossRef]

58. Laudisi, F.; Stolfi, C.; Monteleone, G. Impact of Food Additives on Gut Homeostasis. Nutrients 2019, 11, 2334. [CrossRef]

59. Rizzello, F.; Spisni, E.; Giovanardi, E.; Imbesi, V.; Salice, M.; Alvisi, P.; Valerii, M.C.; Gionchetti, P. Implications of the Westernized Diet in the Onset and Progression of IBD. Nutrients 2019, 11, 1033. [CrossRef]

60. Smith, P.M.; Howitt, M.R.; Panikov, N.; Michaud, M.; Gallini, C.A.; Bohlooly, Y.M.; Glickman, J.N.; Garrett, W.S. The microbial metabolites, short-chain fatty acids, regulate colonic Treg cell homeostasis. Science 2013, 341, 569-573. [CrossRef]

61. Devkota, S.; Wang, Y.; Musch, M.W.; Leone, V.; Fehlner-Peach, H.; Nadimpalli, A.; Antonopoulos, D.A.; Jabri, B.; Chang, E.B. Dietary-fat-induced taurocholic acid promotes pathobiont expansion and colitis in Il10-/- mice. Nature 2012, 487, 104-108. [CrossRef] [PubMed]

62. Zinocker, M.K.; Lindseth, I.A. The Western Diet-Microbiome-Host Interaction and Its Role in Metabolic Disease. Nutrients 2018, 10, 365. [CrossRef] [PubMed]

63. Marion-Letellier, R.; Amamou, A.; Savoye, G.; Ghosh, S. Inflammatory Bowel Diseases and Food Additives: To Add Fuel on the Flames! Nutrients 2019, 11, 1111. [CrossRef] [PubMed]

64. Laffin, M.; Fedorak, R.; Zalasky, A.; Park, H.; Gill, A.; Agrawal, A.; Keshteli, A.; Hotte, N.; Madsen, K.L. A high-sugar diet rapidly enhances susceptibility to colitis via depletion of luminal short-chain fatty acids in mice. Sci. Rep. 2019, 9, 12294. [CrossRef]

65. Li, X.; Wei, X.; Sun, Y.; Du, J.; Li, X.; Xun, Z.; Li, Y.C. High-fat diet promotes experimental colitis by inducing oxidative stress in the colon. Am. J. Physiol. Gastrointest. Liver Physiol. 2019, 317, G453-G462. [CrossRef] [PubMed] 
66. Scaioli, E.; Liverani, E.; Belluzzi, A. The Imbalance between n-6/n-3 Polyunsaturated Fatty Acids and Inflammatory Bowel Disease: A Comprehensive Review and Future Therapeutic Perspectives. Int. J. Mol. Sci. 2017, 18, 2619. [CrossRef] [PubMed]

67. Simopoulos, A.P. The importance of the ratio of omega-6/omega-3 essential fatty acids. Biomed. Pharmacother. 2002, 56, 365-379. [CrossRef]

68. Chiba, M.; Nakane, K.; Komatsu, M. Westernized Diet is the Most Ubiquitous Environmental Factor in Inflammatory Bowel Disease. Perm. J. 2019, 23, 18-107. [CrossRef] [PubMed]

69. Gu, P.; Feagins, L.A. Dining With Inflammatory Bowel Disease: A Review of the Literature on Diet in the Pathogenesis and Management of IBD. Inflamm. Bowel Dis. 2020, 26, 181-191. [CrossRef] [PubMed]

70. De Filippo, C.; Di Paola, M.; Ramazzotti, M.; Albanese, D.; Pieraccini, G.; Banci, E.; Miglietta, F.; Cavalieri, D.; Lionetti, P. Diet, Environments, and Gut Microbiota. A Preliminary Investigation in Children Living in Rural and Urban Burkina Faso and Italy. Front. Microbiol. 2017, 8, 1979. [CrossRef] [PubMed]

71. Raoul, P.; Cintoni, M.; Palombaro, M.; Basso, L.; Rinninella, E.; Gasbarrini, A.; Mele, M.C. Food Additives, a Key Environmental Factor in the Development of IBD through Gut Dysbiosis. Microorganisms 2022, 10, 167. [CrossRef]

72. Ghebretatios, M.; Schaly, S.; Prakash, S. Nanoparticles in the Food Industry and Their Impact on Human Gut Microbiome and Diseases. Int. J. Mol. Sci. 2021, 22, 1942. [CrossRef] [PubMed]

73. Campanale, C.; Massarelli, C.; Savino, I.; Locaputo, V.; Uricchio, V.F. A Detailed Review Study on Potential Effects of Microplastics and Additives of Concern on Human Health. Int. J. Environ. Res. Public Health 2020, 17, 1212. [CrossRef] [PubMed]

74. Wright, S.L.; Kelly, F.J. Plastic and Human Health: A Micro Issue? Environ. Sci. Technol. 2017, 51, 6634-6647. [CrossRef]

75. Weir, A.; Westerhoff, P.; Fabricius, L.; Hristovski, K.; von Goetz, N. Titanium dioxide nanoparticles in food and personal care products. Environ. Sci. Technol. 2012, 46, 2242-2250. [CrossRef] [PubMed]

76. Winkler, H.C.; Notter, T.; Meyer, U.; Naegeli, H. Critical review of the safety assessment of titanium dioxide additives in food. J. Nanobiotechnology 2018, 16, 51. [CrossRef] [PubMed]

77. Jovanovic, B. Critical review of public health regulations of titanium dioxide, a human food additive. Integr. Environ. Assess. Manag. 2015, 11, 10-20. [CrossRef] [PubMed]

78. CFR-Code of Federal Regulations Title 21. Available online: https://www.accessdata.fda.gov/scripts/cdrh/cfdocs/cfCFR/ CFRSearch.cfm?fr=73.575 (accessed on 18 January 2022).

79. Hwang, J.S.; Yu, J.; Kim, H.M.; Oh, J.M.; Choi, S.J. Food Additive Titanium Dioxide and Its Fate in Commercial Foods. Nanomaterials 2019, 9, 1175. [CrossRef] [PubMed]

80. Younes, M. EFSA Panel on Food Additives and Nutrient Sources added to Food (ANS); Re-evaluation of titanium dioxide (E 171) as a food additive. EFSA J. 2016, 14, e05088.

81. Rompelberg, C.; Heringa, M.B.; van Donkersgoed, G.; Drijvers, J.; Roos, A.; Westenbrink, S.; Peters, R.; van Bemmel, G.; Brand, W.; Oomen, A.G. Oral intake of added titanium dioxide and its nanofraction from food products, food supplements and toothpaste by the Dutch population. Nanotoxicology 2016, 10, 1404-1414. [CrossRef] [PubMed]

82. Titanium Dioxide (TiO2)-A Global Market Overview. Available online: https:/ / www.researchandmarkets.com/reports/3801998/ titanium-dioxide-tio2-a-global-market-overview (accessed on 18 January 2022).

83. Titanium Dioxide Market by Grade (Rutile, Anatase), Application (Paints \& Coatings, Pulp \& Paper, Plastics, Cosmetics, Ink), and Region-Global Forecast To 2021. Available online: https:/ / www.marketsandmarkets.com/Market-Reports/titanium-dioxidemarket-225276554.html\#: \{\}:text=Up\%20to\%205)-, The \%20global\%20titanium\%20dioxide\%20market $\% 20$ is $\% 20$ projected $\% 20$ to \%20grow\%20from, 5.8\%25\%20between\%202016\%20and\%202021.\&text=The\%20Asia\%2DPacific\%20region\%20is,titanium\% 20dioxide\%20across $\% 20$ the $\% 20$ globe (accessed on 18 January 2022).

84. European Food Safety Authority (EFSA). Opinion of the Scientific Panel on food additives, flavourings, processing aids and materials in contact with food (AFC) on Titanium dioxide. EFSA J. 2005, 3, 163. [CrossRef]

85. Geiss, O.; Ponti, J.; Senaldi, C.; Bianchi, I.; Mehn, D.; Barrero, J.; Gilliland, D.; Matissek, R.; Anklam, E. Characterisation of food grade titania with respect to nanoparticle content in pristine additives and in their related food products. Food Addit. Contam. Part A Chem. Anal. Control. Expo. Risk Assess. 2020, 37, 239-253. [CrossRef] [PubMed]

86. Faust, J.J.; Doudrick, K.; Yang, Y.; Westerhoff, P.; Capco, D.G. Food grade titanium dioxide disrupts intestinal brush border microvilli in vitro independent of sedimentation. Cell Biol. Toxicol. 2014, 30, 169-188. [CrossRef] [PubMed]

87. Yang, Y.; Doudrick, K.; Bi, X.; Hristovski, K.; Herckes, P.; Westerhoff, P.; Kaegi, R. Characterization of food-grade titanium dioxide: The presence of nanosized particles. Environ. Sci. Technol. 2014, 48, 6391-6400. [CrossRef]

88. Peters, R.J.; van Bemmel, G.; Herrera-Rivera, Z.; Helsper, H.P.; Marvin, H.J.; Weigel, S.; Tromp, P.C.; Oomen, A.G.; Rietveld, A.G.; Bouwmeester, H. Characterization of titanium dioxide nanoparticles in food products: Analytical methods to define nanoparticles. J. Agric. Food Chem. 2014, 62, 6285-6293. [CrossRef]

89. The European Union. Regulation (EU) No 1169/2011 of the European Parliament and of the Council. Off. J. Eur. Union 2011, 20, 168-213.

90. EFSA Panel on Food Additives and Nutrient Sources added to Food (ANS); Younes, M.; Aggett, P.; Aguilar, F.; Crebelli, R.; Dusemund, B.; Filipic, M.; Frutos, M.J.; Galtier, P.; Gott, D.; et al. Evaluation of four new studies on the potential toxicity of titanium dioxide used as a food additive (E 171). EFSA J. 2018, 16, e05366. [CrossRef] [PubMed]

91. Bachler, G.; von Goetz, N.; Hungerbuhler, K. Using physiologically based pharmacokinetic (PBPK) modeling for dietary risk assessment of titanium dioxide (TiO2) nanoparticles. Nanotoxicology 2015, 9, 373-380. [CrossRef] 
92. Chen, X.X.; Cheng, B.; Yang, Y.X.; Cao, A.; Liu, J.H.; Du, L.J.; Liu, Y.; Zhao, Y.; Wang, H. Characterization and preliminary toxicity assay of nano-titanium dioxide additive in sugar-coated chewing gum. Small 2013, 9, 1765-1774. [CrossRef]

93. Specifications for the Identity and Purity of Food Additives and Their Toxicological Evaluation: Some Food Colours, Emulsifiers, Stabilizers, Anticaking Agents, and Certain other Substances, Thirteenth Report of the Joint FAO/WHO Expert Committee on Food Additives. Available online: https://apps.who.int/iris/handle/10665/40773 (accessed on 18 January 2022).

94. IARC Working Group on the Evaluation of Carcinogenic Risks to Humans. Carbon black, titanium dioxide, and talc. IARC Monogr. Eval. Carcinog. Risks Hum. 2010, 93, 1-413.

95. Heringa, M.B.; Geraets, L.; van Eijkeren, J.C.; Vandebriel, R.J.; de Jong, W.H.; Oomen, A.G. Risk assessment of titanium dioxide nanoparticles via oral exposure, including toxicokinetic considerations. Nanotoxicology 2016, 10, 1515-1525. [CrossRef] [PubMed]

96. Bettini, S.; Boutet-Robinet, E.; Cartier, C.; Comera, C.; Gaultier, E.; Dupuy, J.; Naud, N.; Tache, S.; Grysan, P.; Reguer, S.; et al. Food-grade $\mathrm{TiO}_{2}$ impairs intestinal and systemic immune homeostasis, initiates preneoplastic lesions and promotes aberrant crypt development in the rat colon. Sci. Rep. 2017, 7, 40373. [CrossRef] [PubMed]

97. Guo, Z.; Martucci, N.J.; Moreno-Olivas, F.; Tako, E.; Mahler, G.J. Titanium Dioxide Nanoparticle Ingestion Alters Nutrient Absorption in an In Vitro Model of the Small Intestine. NanoImpact 2017, 5, 70-82. [CrossRef] [PubMed]

98. Proquin, H.; Rodriguez-Ibarra, C.; Moonen, C.; Urrutia Ortega, I.M.; Briede, J.J.; de Kok, T.M.; van Loveren, H.; Irasema Chirino, Y. Titanium dioxide food additive (E171) induces ROS formation and genotoxicity: Contribution of micro and nano-sized fractions. Mutagenesis 2018, 33, 267-268. [CrossRef] [PubMed]

99. Athinarayanan, J.; Alshatwi, A.A.; Periasamy, V.S.; Al-Warthan, A.A. Identification of nanoscale ingredients in commercial food products and their induction of mitochondrially mediated cytotoxic effects on human mesenchymal stem cells. J. Food Sci. 2015, 80, N459-N464. [CrossRef]

100. Periasamy, V.S.; Athinarayanan, J.; Al-Hadi, A.M.; Juhaimi, F.A.; Mahmoud, M.H.; Alshatwi, A.A. Identification of titanium dioxide nanoparticles in food products: Induce intracellular oxidative stress mediated by TNF and CYP1A genes in human lung fibroblast cells. Environ. Toxicol. Pharmacol. 2015, 39, 176-186. [CrossRef] [PubMed]

101. Farrell, T.P.; Magnuson, B. Absorption, Distribution and Excretion of Four Forms of Titanium Dioxide Pigment in the Rat. J. Food Sci. 2017, 82, 1985-1993. [CrossRef] [PubMed]

102. Jia, X.; Wang, S.; Zhou, L.; Sun, L. The Potential Liver, Brain, and Embryo Toxicity of Titanium Dioxide Nanoparticles on Mice. Nanoscale Res. Lett. 2017, 12, 478. [CrossRef]

103. Subject: Ban on the Use of Titanium Dioxide (E 171) in Food. Available online: https://www.europarl.europa.eu/doceo/ document/E-9-2019-003009_EN.html (accessed on 18 January 2022).

104. Legifrance. Legifrance. Beschluss vom 17. April 2019 zur Aussetzung des Inverkehrbringens von Lebensmitteln mit dem Zusatz E 171 (Titandioxid-TiO2). Available online: https:/ / www.legifrance.gouv.fr/jorf/id/JORFTEXT000044791848 (accessed on 18 January 2022).

105. Goyens, M.; Muffet, C.; Wilkes, J.; Wates, J.; Wolfschmidt, M.; Jensen, G.K.; Caterbow, A.; Cimmarusti, F.; Gabizon, S. Subject: Civil Society Organisations Demand the Removal of E171 from the EU List of Permitted Food Additives. Available online: https:/ / www.safefoodadvocacy.eu/wp-content/uploads/2019/05/JOINT-LETTER-BEUC-L-2019-097-Vice-PresidentJyrki-Katainen.pdf (accessed on 18 January 2022).

106. Hutton, L.L.B.C.N. European Parliament Calls on EC to Ban Titanium Dioxide (E171) in Food. Available online: https://nanotech. lawbc.com/2020/10/european-parliament-calls-on-ec-to-ban-titanium-dioxide-e171-in-food/ (accessed on 18 January 2022).

107. Aktuelles Europäisches Parlament. Parliament Objects to Legislation on Food Products that Might Be Harmful to Kids. Available online: https: / /www.europarl.europa.eu/news/de/press-room/20201002IPR88447/parliament-objects-to-legislation-on-foodproducts-that-might-be-harmful-to-kids (accessed on 18 January 2022).

108. Brun, E.; Barreau, F.; Veronesi, G.; Fayard, B.; Sorieul, S.; Chaneac, C.; Carapito, C.; Rabilloud, T.; Mabondzo, A.; Herlin-Boime, N.; et al. Titanium dioxide nanoparticle impact and translocation through ex vivo, in vivo and in vitro gut epithelia. Part Fibre Toxicol. 2014, 11, 13. [CrossRef] [PubMed]

109. Wang, J.; Zhou, G.; Chen, C.; Yu, H.; Wang, T.; Ma, Y.; Jia, G.; Gao, Y.; Li, B.; Sun, J.; et al. Acute toxicity and biodistribution of different sized titanium dioxide particles in mice after oral administration. Toxicol. Lett. 2007, 168, 176-185. [CrossRef]

110. Baranowska-Wojcik, E.; Szwajgier, D.; Oleszczuk, P.; Winiarska-Mieczan, A. Effects of Titanium Dioxide Nanoparticles Exposure on Human Health-a Review. Biol. Trace Elem. Res. 2020, 193, 118-129. [CrossRef] [PubMed]

111. McClements, D.J.; Xiao, H.; Demokritou, P. Physicochemical and colloidal aspects of food matrix effects on gastrointestinal fate of ingested inorganic nanoparticles. Adv. Colloid. Interface Sci. 2017, 246, 165-180. [CrossRef]

112. Warheit, D.B.; Donner, E.M. Risk assessment strategies for nanoscale and fine-sized titanium dioxide particles: Recognizing hazard and exposure issues. Food Chem. Toxicol. 2015, 85, 138-147. [CrossRef] [PubMed]

113. Jones, K.; Morton, J.; Smith, I.; Jurkschat, K.; Harding, A.H.; Evans, G. Human in vivo and in vitro studies on gastrointestinal absorption of titanium dioxide nanoparticles. Toxicol. Lett. 2015, 233, 95-101. [CrossRef] [PubMed]

114. Geraets, L.; Oomen, A.G.; Krystek, P.; Jacobsen, N.R.; Wallin, H.; Laurentie, M.; Verharen, H.W.; Brandon, E.F.; de Jong, W.H. Tissue distribution and elimination after oral and intravenous administration of different titanium dioxide nanoparticles in rats. Part Fibre Toxicol. 2014, 11, 30. [CrossRef] [PubMed]

115. Cho, W.S.; Kang, B.C.; Lee, J.K.; Jeong, J.; Che, J.H.; Seok, S.H. Comparative absorption, distribution, and excretion of titanium dioxide and zinc oxide nanoparticles after repeated oral administration. Part Fibre Toxicol. 2013, 10, 9. [CrossRef] [PubMed] 
116. MacNicoll, A.; Kelly, M.; Aksoy, H.; Kramer, E.; Bouwmeester, H.; Chaudhry, Q. A study of the uptake and biodistribution of nano-titanium dioxide using in vitro and in vivo models of oral intake. J. Nanoparticle Res. 2015, 17, 66. [CrossRef]

117. Heringa, M.B.; Peters, R.J.B.; Bleys, R.; van der Lee, M.K.; Tromp, P.C.; van Kesteren, P.C.E.; van Eijkeren, J.C.H.; Undas, A.K.; Oomen, A.G.; Bouwmeester, H. Detection of titanium particles in human liver and spleen and possible health implications. Part Fibre Toxicol. 2018, 15, 15. [CrossRef] [PubMed]

118. Borm, P.J.; Robbins, D.; Haubold, S.; Kuhlbusch, T.; Fissan, H.; Donaldson, K.; Schins, R.; Stone, V.; Kreyling, W.; Lademann, J.; et al. The potential risks of nanomaterials: A review carried out for ECETOC. Part Fibre Toxicol. $2006,3,11$. [CrossRef]

119. Ruiz, P.A.; Moron, B.; Becker, H.M.; Lang, S.; Atrott, K.; Spalinger, M.R.; Scharl, M.; Wojtal, K.A.; Fischbeck-Terhalle, A.; FreyWagner, I.; et al. Titanium dioxide nanoparticles exacerbate DSS-induced colitis: Role of the NLRP3 inflammasome. Gut 2017, 66, 1216-1224. [CrossRef] [PubMed]

120. Talamini, L.; Gimondi, S.; Violatto, M.B.; Fiordaliso, F.; Pedica, F.; Tran, N.L.; Sitia, G.; Aureli, F.; Raggi, A.; Nelissen, I.; et al Repeated administration of the food additive E171 to mice results in accumulation in intestine and liver and promotes an inflammatory status. Nanotoxicology 2019, 13, 1087-1101. [CrossRef] [PubMed]

121. Yang, J.; Luo, M.; Tan, Z.; Dai, M.; Xie, M.; Lin, J.; Hua, H.; Ma, Q.; Zhao, J.; Liu, A. Oral administration of nano-titanium dioxide particle disrupts hepatic metabolic functions in a mouse model. Environ. Toxicol. Pharmacol. 2017, 49, 112-118. [CrossRef]

122. Chen, Z.; Wang, Y.; Wang, X.; Zhuo, L.; Chen, S.; Tang, S.; Zhao, L.; Luan, X.; Jia, G. Effect of titanium dioxide nanoparticles on glucose homeostasis after oral administration. J. Appl. Toxicol. 2018, 38, 810-823. [CrossRef] [PubMed]

123. Jani, P.U.; McCarthy, D.E.; Florence, A.T. Titanium dioxide (rutile) particle uptake from the rat GI tract and translocation to systemic organs after oral administration. Int. J. Pharm. 1994, 105, 157-168. [CrossRef]

124. Zeman, T.; Loh, E.W.; Cierny, D.; Sery, O. Penetration, distribution and brain toxicity of titanium nanoparticles in rodents' body: A review. IET Nanobiotechnol. 2018, 12, 695-700. [CrossRef] [PubMed]

125. Pedata, P.; Ricci, G.; Malorni, L.; Venezia, A.; Cammarota, M.; Volpe, M.G.; Iannaccone, N.; Guida, V.; Schiraldi, C.; Romano, M.; et al. In vitro intestinal epithelium responses to titanium dioxide nanoparticles. Food Res. Int. 2019, 119, 634-642. [CrossRef]

126. Limage, R.; Tako, E.; Kolba, N.; Guo, Z.; Garcia-Rodriguez, A.; Marques, C.N.H.; Mahler, G.J. TiO 2 Nanoparticles and Commensal Bacteria Alter Mucus Layer Thickness and Composition in a Gastrointestinal Tract Model. Small 2020, 16, e2000601. [CrossRef] [PubMed]

127. Zhu, X.; Zhao, L.; Liu, Z.; Zhou, Q.; Zhu, Y.; Zhao, Y.; Yang, X. Long-term exposure to titanium dioxide nanoparticles promotes diet-induced obesity through exacerbating intestinal mucus layer damage and microbiota dysbiosis. Nano Res. 2021, 14, 1512-1522. [CrossRef]

128. Powell, J.J.; Ainley, C.C.; Harvey, R.S.; Mason, I.M.; Kendall, M.D.; Sankey, E.A.; Dhillon, A.P.; Thompson, R.P. Characterisation of inorganic microparticles in pigment cells of human gut associated lymphoid tissue. Gut 1996, 38, 390-395. [CrossRef] [PubMed]

129. Lomer, M.C.; Thompson, R.P.; Powell, J.J. Fine and ultrafine particles of the diet: Influence on the mucosal immune response and association with Crohn's disease. Proc. Nutr. Soc. 2002, 61, 123-130. [CrossRef]

130. Mu, W.; Wang, Y.; Huang, C.; Fu, Y.; Li, J.; Wang, H.; Jia, X.; Ba, Q. Effect of Long-Term Intake of Dietary Titanium Dioxide Nanoparticles on Intestine Inflammation in Mice. J. Agric. Food Chem. 2019, 67, 9382-9389. [CrossRef] [PubMed]

131. Li, J.; Yang, S.; Lei, R.; Gu, W.; Qin, Y.; Ma, S.; Chen, K.; Chang, Y.; Bai, X.; Xia, S.; et al. Oral administration of rutile and anatase TiO2 nanoparticles shifts mouse gut microbiota structure. Nanoscale 2018, 10, 7736-7745. [CrossRef] [PubMed]

132. Pinget, G.; Tan, J.; Janac, B.; Kaakoush, N.O.; Angelatos, A.S.; O’Sullivan, J.; Koay, Y.C.; Sierro, F.; Davis, J.; Divakarla, S.K.; et al Impact of the Food Additive Titanium Dioxide (E171) on Gut Microbiota-Host Interaction. Front. Nutr. 2019, 6, 57. [CrossRef]

133. Nogueira, C.M.; de Azevedo, W.M.; Dagli, M.L.; Toma, S.H.; Leite, A.Z.; Lordello, M.L.; Nishitokukado, I.; Ortiz-Agostinho, C.L.; Duarte, M.I.; Ferreira, M.A.; et al. Titanium dioxide induced inflammation in the small intestine. World J. Gastroenterol. 2012, 18, 4729-4735. [CrossRef]

134. Yao, L.; Tang, Y.; Chen, B.; Hong, W.; Xu, X.; Liu, Y.; Aguilar, Z.P.; Xu, H. Oral exposure of titanium oxide nanoparticles induce ileum physical barrier dysfunction via Th1/Th2 imbalance. Environ. Toxicol. 2020, 35, 982-990. [CrossRef]

135. Yan, J.; Wang, D.; Li, K.; Chen, Q.; Lai, W.; Tian, L.; Lin, B.; Tan, Y.; Liu, X.; Xi, Z. Toxic effects of the food additives titanium dioxide and silica on the murine intestinal tract: Mechanisms related to intestinal barrier dysfunction involved by gut microbiota. Environ. Toxicol. Pharmacol. 2020, 80, 103485. [CrossRef] [PubMed]

136. Huang, C.; Sun, M.; Yang, Y.; Wang, F.; Ma, X.; Li, J.; Wang, Y.; Ding, Q.; Ying, H.; Song, H.; et al. Titanium dioxide nanoparticles prime a specific activation state of macrophages. Nanotoxicology 2017, 11, 737-750. [CrossRef]

137. Gao, Y.; Li, T.; Duan, S.; Lyu, L.; Li, Y.; Xu, L.; Wang, Y. Impact of titanium dioxide nanoparticles on intestinal community in 2,4,6-trinitrobenzenesulfonic acid (TNBS)-induced acute colitis mice and the intervention effect of vitamin E. Nanoscale 2021, 13, 1842-1862. [CrossRef]

138. Urrutia-Ortega, I.M.; Garduno-Balderas, L.G.; Delgado-Buenrostro, N.L.; Freyre-Fonseca, V.; Flores-Flores, J.O.; Gonzalez-Robles, A.; Pedraza-Chaverri, J.; Hernandez-Pando, R.; Rodriguez-Sosa, M.; Leon-Cabrera, S.; et al. Food-grade titanium dioxide exposure exacerbates tumor formation in colitis associated cancer model. Food Chem. Toxicol. 2016, 93, 20-31. [CrossRef] 
139. Dupaul-Chicoine, J.; Yeretssian, G.; Doiron, K.; Bergstrom, K.S.; McIntire, C.R.; LeBlanc, P.M.; Meunier, C.; Turbide, C.; Gros, P.; Beauchemin, N.; et al. Control of intestinal homeostasis, colitis, and colitis-associated colorectal cancer by the inflammatory caspases. Immunity 2010, 32, 367-378. [CrossRef]

140. Dobbins, W.O., 3rd. Dysplasia and malignancy in inflammatory bowel disease. Annu. Rev. Med. 1984, 35, 33-48. [CrossRef] [PubMed]

141. Lakatos, P.L.; Lakatos, L. Risk for colorectal cancer in ulcerative colitis: Changes, causes and management strategies. World J. Gastroenterol. 2008, 14, 3937-3947. [CrossRef] [PubMed]

142. Abraham, B.P. Cancer surveillance in ulcerative colitis and Crohn's disease: New strategies. Curr. Opin. Gastroenterol. 2016, 32, 32-37. [CrossRef]

143. Francescone, R.; Hou, V.; Grivennikov, S.I. Cytokines, IBD, and colitis-associated cancer. Inflamm. Bowel Dis. 2015, 21, 409-418. [CrossRef] [PubMed]

144. Munkholm, P. Review article: The incidence and prevalence of colorectal cancer in inflammatory bowel disease. Aliment. Pharmacol. Ther. 2003, 18 (Suppl. 2), 1-5. [CrossRef]

145. Averboukh, F.; Ziv, Y.; Kariv, Y.; Zmora, O.; Dotan, I.; Klausner, J.M.; Rabau, M.; Tulchinsky, H. Colorectal carcinoma in inflammatory bowel disease: A comparison between Crohn's and ulcerative colitis. Colorectal. Dis. 2011, 13, 1230-1235. [CrossRef]

146. Sugita, A.; Greenstein, A.J.; Ribeiro, M.B.; Sachar, D.B.; Bodian, C.; Panday, A.K.; Szporn, A.; Pozner, J.; Heimann, T.; Palmer, M.; et al. Survival with colorectal cancer in ulcerative colitis. A study of 102 cases. Ann. Surg. 1993, 218, 189-195. [CrossRef]

147. Watanabe, T.; Konishi, T.; Kishimoto, J.; Kotake, K.; Muto, T.; Sugihara, K.; Japanese Society for Cancer of the Colon and Rectum Ulcerative colitis-associated colorectal cancer shows a poorer survival than sporadic colorectal cancer: A nationwide Japanese study. Inflamm. Bowel Dis. 2011, 17, 802-808. [CrossRef]

148. Kavanagh, D.O.; Carter, M.C.; Keegan, D.; Doherty, G.; Smith, M.J.; Hyland, J.M.; Mulcahy, H.; Sheahan, K.; PR, O.C.; DP, O.D.; et al. Management of colorectal cancer in patients with inflammatory bowel disease. Tech. Coloproctol. 2014, 18, 23-28. [CrossRef]

149. PlasticsEurope. Plastics-The Facts 2020. Available online: https://plasticseurope.org/knowledge-hub/plastics-the-facts-2020/ (accessed on 18 January 2022).

150. Phillips, M.B.; Bonner, T.H. Occurrence and amount of microplastic ingested by fishes in watersheds of the Gulf of Mexico. Mar Pollut. Bull. 2015, 100, 264-269. [CrossRef]

151. Geyer, R.; Jambeck, J.R.; Law, K.L. Production, use, and fate of all plastics ever made. Sci. Adv. 2017, 3, e1700782. [CrossRef]

152. Ajith, N.; Arumugam, S.; Parthasarathy, S.; Manupoori, S.; Janakiraman, S. Global distribution of microplastics and its impact on marine environment-a review. Environ. Sci. Pollut. Res. Int. 2020, 27, 25970-25986. [CrossRef]

153. Leon, V.M.; Garcia-Aguera, I.; Molto, V.; Fernandez-Gonzalez, V.; Llorca-Perez, L.; Andrade, J.M.; Muniategui-Lorenzo, S.; Campillo, J.A. PAHs, pesticides, personal care products and plastic additives in plastic debris from Spanish Mediterranean beaches. Sci. Total Environ. 2019, 670, 672-684. [CrossRef] [PubMed]

154. Lei, K.; Qiao, F.; Liu, Q.; Wei, Z.; Qi, H.; Cui, S.; Yue, X.; Deng, Y.; An, L. Microplastics releasing from personal care and cosmetic products in China. Mar. Pollut. Bull. 2017, 123, 122-126. [CrossRef] [PubMed]

155. Praveena, S.M.; Shaifuddin, S.N.M.; Akizuki, S. Exploration of microplastics from personal care and cosmetic products and its estimated emissions to marine environment: An evidence from Malaysia. Mar. Pollut. Bull. 2018, 136, 135-140. [CrossRef]

156. Andrady, A.L. The plastic in microplastics: A review. Mar. Pollut. Bull. 2017, 119, 12-22. [CrossRef]

157. Andrady, A.L. Microplastics in the marine environment. Mar. Pollut. Bull. 2011, 62, 1596-1605. [CrossRef]

158. Thushari, G.G.N.; Senevirathna, J.D.M. Plastic pollution in the marine environment. Heliyon 2020, 6, e04709. [CrossRef]

159. De Falco, F.; Di Pace, E.; Cocca, M.; Avella, M. The contribution of washing processes of synthetic clothes to microplastic pollution. Sci. Rep. 2019, 9, 6633. [CrossRef]

160. Kole, P.J.; Lohr, A.J.; Van Belleghem, F.; Ragas, A.M.J. Wear and Tear of Tyres: A Stealthy Source of Microplastics in the Environment. Int. J. Environ. Res. Public Health 2017, 14, 1265. [CrossRef]

161. Thompson, R.; Moore, C.; Andrady, A.; Gregory, M.; Takada, H.; Weisberg, S. New directions in plastic debris. Science 2005, 310, 1117. [CrossRef]

162. Thompson, R.C.; Olsen, Y.; Mitchell, R.P.; Davis, A.; Rowland, S.J.; John, A.W.; McGonigle, D.; Russell, A.E. Lost at sea: Where is all the plastic? Science 2004, 304, 838. [CrossRef]

163. Lei, L.; Wu, S.; Lu, S.; Liu, M.; Song, Y.; Fu, Z.; Shi, H.; Raley-Susman, K.M.; He, D. Microplastic particles cause intestinal damage and other adverse effects in zebrafish Danio rerio and nematode Caenorhabditis elegans. Sci. Total Environ. 2018, 619-620, 1-8 [CrossRef]

164. Jin, Y.; Xia, J.; Pan, Z.; Yang, J.; Wang, W.; Fu, Z. Polystyrene microplastics induce microbiota dysbiosis and inflammation in the gut of adult zebrafish. Environ. Pollut. 2018, 235, 322-329. [CrossRef]

165. Xu, X.Y.; Lee, W.T.; Chan, A.K.Y.; Lo, H.S.; Shin, P.K.S.; Cheung, S.G. Microplastic ingestion reduces energy intake in the clam Atactodea striata. Mar. Pollut. Bull. 2017, 124, 798-802. [CrossRef]

166. Prata, J.C.; da Costa, J.P.; Lopes, I.; Duarte, A.C.; Rocha-Santos, T. Environmental exposure to microplastics: An overview on possible human health effects. Sci. Total Environ. 2020, 702, 134455. [CrossRef] 
167. Patil, S.; Bafana, A.; Naoghare, P.K.; Krishnamurthi, K.; Sivanesan, S. Environmental prevalence, fate, impacts, and mitigation of microplastics-a critical review on present understanding and future research scope. Environ. Sci. Pollut. Res. Int. 2021, 28, 4951-4974. [CrossRef]

168. Watts, A.J.; Urbina, M.A.; Corr, S.; Lewis, C.; Galloway, T.S. Ingestion of Plastic Microfibers by the Crab Carcinus maenas and Its Effect on Food Consumption and Energy Balance. Environ. Sci. Technol. 2015, 49, 14597-14604. [CrossRef]

169. Wright, S.L.; Rowe, D.; Thompson, R.C.; Galloway, T.S. Microplastic ingestion decreases energy reserves in marine worms. Curr. Biol. 2013, 23, R1031-R1033. [CrossRef]

170. Wen, B.; Zhang, N.; Jin, S.R.; Chen, Z.Z.; Gao, J.Z.; Liu, Y.; Liu, H.P.; Xu, Z. Microplastics have a more profound impact than elevated temperatures on the predatory performance, digestion and energy metabolism of an Amazonian cichlid. Aquat Toxicol. 2018, 195, 67-76. [CrossRef]

171. Deng, Y.; Zhang, Y.; Lemos, B.; Ren, H. Tissue accumulation of microplastics in mice and biomarker responses suggest widespread health risks of exposure. Sci. Rep. 2017, 7, 46687. [CrossRef]

172. Brandts, I.; Teles, M.; Tvarijonaviciute, A.; Pereira, M.L.; Martins, M.A.; Tort, L.; Oliveira, M. Effects of polymethylmethacrylate nanoplastics on Dicentrarchus labrax. Genomics 2018, 110, 435-441. [CrossRef]

173. Canesi, L.; Ciacci, C.; Bergami, E.; Monopoli, M.P.; Dawson, K.A.; Papa, S.; Canonico, B.; Corsi, I. Evidence for immunomodulation and apoptotic processes induced by cationic polystyrene nanoparticles in the hemocytes of the marine bivalve Mytilus. Mar. Environ. Res. 2015, 111, 34-40. [CrossRef]

174. Detree, C.; Gallardo-Escarate, C. Single and repetitive microplastics exposures induce immune system modulation and homeostasis alteration in the edible mussel Mytilus galloprovincialis. Fish Shellfish Immunol. 2018, 83, 52-60. [CrossRef]

175. Dris, R.; Gasperi, J.; Mirande, C.; Mandin, C.; Guerrouache, M.; Langlois, V.; Tassin, B. A first overview of textile fibers, including microplastics, in indoor and outdoor environments. Environ. Pollut. 2017, 221, 453-458. [CrossRef] [PubMed]

176. Prata, J.C. Airborne microplastics: Consequences to human health? Environ. Pollut. 2018, 234, 115-126. [CrossRef]

177. Vianello, A.; Jensen, R.L.; Liu, L.; Vollertsen, J. Simulating human exposure to indoor airborne microplastics using a Breathing Thermal Manikin. Sci. Rep. 2019, 9, 8670. [CrossRef] [PubMed]

178. Pimentel, J.C.; Avila, R.; Lourenco, A.G. Respiratory disease caused by synthetic fibres: A new occupational disease. Thorax 1975, 30, 204-219. [CrossRef] [PubMed]

179. Atis, S.; Tutluoglu, B.; Levent, E.; Ozturk, C.; Tunaci, A.; Sahin, K.; Saral, A.; Oktay, I.; Kanik, A.; Nemery, B. The respiratory effects of occupational polypropylene flock exposure. Eur. Respir. J. 2005, 25, 110-117. [CrossRef] [PubMed]

180. Pauly, J.L.; Stegmeier, S.J.; Allaart, H.A.; Cheney, R.T.; Zhang, P.J.; Mayer, A.G.; Streck, R.J. Inhaled cellulosic and plastic fibers found in human lung tissue. Cancer Epidemiol. Biomarkers Prev. 1998, 7, 419-428.

181. Agarwal, D.K.; Kaw, J.L.; Srivastava, S.P.; Seth, P.K. Some biochemical and histopathological changes induced by polyvinyl chloride dust in rat lung. Environ. Res. 1978, 16, 333-341. [CrossRef]

182. Porter, D.W.; Castranova, V.; Robinson, V.A.; Hubbs, A.F.; Mercer, R.R.; Scabilloni, J.; Goldsmith, T.; Schwegler-Berry, D.; Battelli, L.; Washko, R.; et al. Acute inflammatory reaction in rats after intratracheal instillation of material collected from a nylon flocking plant. J. Toxicol. Environ. Health A 1999, 57, 25-45. [CrossRef] [PubMed]

183. Wang, Z.; Saade, N.K.; Ariya, P.A. Advances in Ultra-Trace Analytical Capability for Micro/Nanoplastics and Water-Soluble Polymers in the Environment: Fresh Falling Urban Snow. Environ. Pollut. 2021, 276, 116698. [CrossRef] [PubMed]

184. Cox, K.D.; Covernton, G.A.; Davies, H.L.; Dower, J.F.; Juanes, F.; Dudas, S.E. Human Consumption of Microplastics. Environ. Sci. Technol. 2019, 53, 7068-7074. [CrossRef] [PubMed]

185. Senathirajah, K.; Attwood, S.; Bhagwat, G.; Carbery, M.; Wilson, S.; Palanisami, T. Estimation of the mass of microplastics ingested-A pivotal first step towards human health risk assessment. J. Hazard. Mater. 2021, 404, 124004. [CrossRef] [PubMed]

186. Schwabl, P.; Koppel, S.; Konigshofer, P.; Bucsics, T.; Trauner, M.; Reiberger, T.; Liebmann, B. Detection of Various Microplastics in Human Stool: A Prospective Case Series. Ann. Intern. Med. 2019, 171, 453-457. [CrossRef]

187. The American Chemical Society. Methods for Microplastics, Nanoplastics and Plastic Monomer Detection and Reporting in Human Tissues. Available online: https://www.acs.org/content/acs/en/pressroom/newsreleases/2020/august/micro-andnanoplastics-detectable-in-human-tissues.html (accessed on 18 January 2022).

188. Al-Sid-Cheikh, M.; Rowland, S.J.; Stevenson, K.; Rouleau, C.; Henry, T.B.; Thompson, R.C. Uptake, Whole-Body Distribution, and Depuration of Nanoplastics by the Scallop Pecten maximus at Environmentally Realistic Concentrations. Environ. Sci. Technol. 2018, 52, 14480-14486. [CrossRef]

189. Avio, C.G.; Gorbi, S.; Milan, M.; Benedetti, M.; Fattorini, D.; d’Errico, G.; Pauletto, M.; Bargelloni, L.; Regoli, F. Pollutants bioavailability and toxicological risk from microplastics to marine mussels. Environ. Pollut. 2015, 198, 211-222. [CrossRef] [PubMed]

190. Grigorakis, S.; Mason, S.A.; Drouillard, K.G. Determination of the gut retention of plastic microbeads and microfibers in goldfish (Carassius auratus). Chemosphere 2017, 169, 233-238. [CrossRef]

191. Sharma, S.; Chatterjee, S. Microplastic pollution, a threat to marine ecosystem and human health: A short review. Environ. Sci. Pollut. Res. Int. 2017, 24, 21530-21547. [CrossRef] [PubMed]

192. Duncan, E.M.; Broderick, A.C.; Fuller, W.J.; Galloway, T.S.; Godfrey, M.H.; Hamann, M.; Limpus, C.J.; Lindeque, P.K.; Mayes, A.G.; Omeyer, L.C.M.; et al. Microplastic ingestion ubiquitous in marine turtles. Glob. Chang. Biol. 2018, 25, 744-752. [CrossRef] 
193. Smith, M.; Love, D.C.; Rochman, C.M.; Neff, R.A. Microplastics in Seafood and the Implications for Human Health. Curr. Environ. Health Rep. 2018, 5, 375-386. [CrossRef] [PubMed]

194. Chae, Y.; Kim, D.; Kim, S.W.; An, Y.J. Trophic transfer and individual impact of nano-sized polystyrene in a four-species freshwater food chain. Sci. Rep. 2018, 8, 284. [CrossRef] [PubMed]

195. Mattsson, K.; Ekvall, M.T.; Hansson, L.A.; Linse, S.; Malmendal, A.; Cedervall, T. Altered behavior, physiology, and metabolism in fish exposed to polystyrene nanoparticles. Environ. Sci. Technol. 2015, 49, 553-561. [CrossRef] [PubMed]

196. Welle, F.; Franz, R. Microplastic in bottled natural mineral water-literature review and considerations on exposure and risk assessment. Food Addit. Contam. Part A Chem Anal. Control Expo. Risk Assess 2018, 35, 2482-2492. [CrossRef] [PubMed]

197. Schymanski, D.; Goldbeck, C.; Humpf, H.U.; Furst, P. Analysis of microplastics in water by micro-Raman spectroscopy: Release of plastic particles from different packaging into mineral water. Water Res. 2018, 129, 154-162. [CrossRef] [PubMed]

198. Shruti, V.C.; Perez-Guevara, F.; Elizalde-Martinez, I.; Kutralam-Muniasamy, G. Toward a unified framework for investigating micro(nano)plastics in packaged beverages intended for human consumption. Environ. Pollut. 2021, 268, 115811. [CrossRef] [PubMed]

199. Ossmann, B.E.; Sarau, G.; Holtmannspotter, H.; Pischetsrieder, M.; Christiansen, S.H.; Dicke, W. Small-sized microplastics and pigmented particles in bottled mineral water. Water Res. 2018, 141, 307-316. [CrossRef] [PubMed]

200. Liebezeit, G.; Liebezeit, E. Non-pollen particulates in honey and sugar. Food Addit. Contam. Part A Chem. Anal. Control Expo. Risk Assess 2013, 30, 2136-2140. [CrossRef] [PubMed]

201. Liebezeit, G.; Liebezeit, E. Synthetic particles as contaminants in German beers. Food Addit. Contam. Part A Chem. Anal. Control Expo. Risk Assess 2014, 31, 1574-1578. [CrossRef]

202. Yang, D.; Shi, H.; Li, L.; Li, J.; Jabeen, K.; Kolandhasamy, P. Microplastic Pollution in Table Salts from China. Environ. Sci. Technol. 2015, 49, 13622-13627. [CrossRef] [PubMed]

203. Eerkes-Medrano, D.; Thompson, R.C.; Aldridge, D.C. Microplastics in freshwater systems: A review of the emerging threats, identification of knowledge gaps and prioritisation of research needs. Water Res. 2015, 75, 63-82. [CrossRef] [PubMed]

204. Kosuth, M.; Mason, S.A.; Wattenberg, E.V. Anthropogenic contamination of tap water, beer, and sea salt. PLoS ONE 2018, 13, e0194970. [CrossRef] [PubMed]

205. Dong, C.D.; Chen, C.W.; Chen, Y.C.; Chen, H.H.; Lee, J.S.; Lin, C.H. Polystyrene microplastic particles: In vitro pulmonary toxicity assessment. J. Hazard. Mater. 2020, 385, 121575. [CrossRef]

206. Wu, S.; Wu, M.; Tian, D.; Qiu, L.; Li, T. Effects of polystyrene microbeads on cytotoxicity and transcriptomic profiles in human Caco-2 cells. Environ. Toxicol. 2020, 35, 495-506. [CrossRef] [PubMed]

207. Braeuning, A. Uptake of microplastics and related health effects: A critical discussion of Deng et al., Scientific reports 7:46687, 2017. Arch. Toxicol. 2019, 93, 219-220. [CrossRef]

208. Bohmert, L.; Stock, V.; Braeuning, A. Plausibility of microplastic uptake in a paper by Deng et al., Scientific reports 7:46687, 2017. Arch. Toxicol. 2019, 93, 217-218. [CrossRef]

209. Xie, X.; Deng, T.; Duan, J.; Xie, J.; Yuan, J.; Chen, M. Exposure to polystyrene microplastics causes reproductive toxicity through oxidative stress and activation of the p38 MAPK signaling pathway. Ecotoxicol. Environ. Saf. 2020, 190, 110133. [CrossRef]

210. Park, E.J.; Han, J.S.; Park, E.J.; Seong, E.; Lee, G.H.; Kim, D.W.; Son, H.Y.; Han, H.Y.; Lee, B.S. Repeated-oral dose toxicity of polyethylene microplastics and the possible implications on reproduction and development of the next generation. Toxicol. Lett. 2020, 324, 75-85. [CrossRef] [PubMed]

211. Jin, H.; Ma, T.; Sha, X.; Liu, Z.; Zhou, Y.; Meng, X.; Chen, Y.; Han, X.; Ding, J. Polystyrene microplastics induced male reproductive toxicity in mice. J. Hazard. Mater. 2021, 401, 123430. [CrossRef]

212. Hou, J.; Lei, Z.; Cui, L.; Hou, Y.; Yang, L.; An, R.; Wang, Q.; Li, S.; Zhang, H.; Zhang, L. Polystyrene microplastics lead to pyroptosis and apoptosis of ovarian granulosa cells via NLRP3/Caspase-1 signaling pathway in rats. Ecotoxicol. Environ. Saf. 2021, 212, 112012. [CrossRef] [PubMed]

213. Luo, T.; Zhang, Y.; Wang, C.; Wang, X.; Zhou, J.; Shen, M.; Zhao, Y.; Fu, Z.; Jin, Y. Maternal exposure to different sizes of polystyrene microplastics during gestation causes metabolic disorders in their offspring. Environ. Pollut. 2019, 255, 113122. [CrossRef] [PubMed]

214. Luo, T.; Wang, C.; Pan, Z.; Jin, C.; Fu, Z.; Jin, Y. Maternal Polystyrene Microplastic Exposure during Gestation and Lactation Altered Metabolic Homeostasis in the Dams and Their F1 and F2 Offspring. Environ. Sci. Technol. 2019, 53, 10978-10992. [CrossRef] [PubMed]

215. da Costa Araujo, A.P.; Malafaia, G. Microplastic ingestion induces behavioral disorders in mice: A preliminary study on the trophic transfer effects via tadpoles and fish. J. Hazard. Mater. 2021, 401, 123263. [CrossRef] [PubMed]

216. Yong, C.Q.Y.; Valiyaveetill, S.; Tang, B.L. Toxicity of Microplastics and Nanoplastics in Mammalian Systems. Int. J. Environ. Res. Public Health 2020, 17, 1509. [CrossRef] [PubMed]

217. Qiao, J.; Chen, R.; Wang, M.; Bai, R.; Cui, X.; Liu, Y.; Wu, C.; Chen, C. Perturbation of gut microbiota plays an important role in micro/nanoplastics-induced gut barrier dysfunction. Nanoscale 2021, 13, 8806-8816. [CrossRef] [PubMed]

218. Schwarzfischer, M.; Spalinger, M.; Scharl, M.; Niechial, A. Ingested nano- and microsized polystyrene particles surpass the intestinal barrier and accumulate in the body. NanoImpact 2022, 25, 100374. [CrossRef] 
219. Torres, J.; Mehandru, S.; Colombel, J.F.; Peyrin-Biroulet, L. Crohn's disease. Lancet 2017, 389, 1741-1755. [CrossRef]

220. Lee, J.Y.; Wasinger, V.C.; Yau, Y.Y.; Chuang, E.; Yajnik, V.; Leong, R.W. Molecular Pathophysiology of Epithelial Barrier Dysfunction in Inflammatory Bowel Diseases. Proteomes 2018, 6, 17. [CrossRef] 